\title{
France: 2006 Article IV Consultation-Staff Report, Staff Supplement; and Public Information Notice on the Executive Board Discussion
}

Under Article IV of the IMF's Articles of Agreement, the IMF holds bilateral discussions with members, usually every year. In the context of the 2006 Article IV consultation with France, the following documents have been released and are included in this package:

- $\quad$ the staff report for the 2006 Article IV consultation, prepared by a staff team of the IMF, following discussions that ended on July 10, 2006, with the officials of France on economic developments and policies. Based on information available at the time of these discussions, the staff report was completed on September 27, 2006. The views expressed in the staff report are those of the staff team and do not necessarily reflect the views of the Executive Board of the IMF;

- a supplement to the staff report of October 19, 2006 updating information on recent developments; and

- $\quad$ a Public Information Notice (PIN) summarizing the views of the Executive Board as expressed during its October 25, 2006 discussion of the staff report that concluded the Article IV consultation.

The document listed below has been or will be separately released.

\section{Selected Issues Paper}

The policy of publication of staff reports and other documents allows for the deletion of marketsensitive information.

To assist the IMF in evaluating the publication policy, reader comments are invited and may be sent by e-mail to publicationpolicy@imf.org.

\author{
Copies of this report are available to the public from \\ International Monetary Fund • Publication Services \\ $70019^{\text {th }}$ Street, N.W. • Washington, D.C. 20431 \\ Telephone: (202) 623-7430 • Telefax: (202) 623-7201 \\ E-mail: publications@imf.org • Internet: http://www.imf.org \\ Price: $\$ 18.00$ a copy

\section{International Monetary Fund Washington, D.C.}





\section{INTERNATIONAL MONETARY FUND}

\section{FRANCE}

\section{Staff Report for the 2006 Article IV Consultation}

Prepared by Staff Representatives for the 2006 Consultation with France

Approved by Michael Deppler and Matthew Fisher

September 27, 2006

\section{Executive Summary}

France's economic short-run outlook is positive, and long-run prospects have improved. The economy is benefiting from the cyclical recovery in Europe and improved demographics. Structural reforms have rendered labor and product markets more flexible and contributed to fiscal consolidation. GDP growth is likely to average somewhat more than $2 \frac{1}{4}$ percent per year during 2006-07, the unemployment rate is expected to continue a steady decline, and the budget deficit should come in at about $23 / 4$ percent of GDP in 2006 and fall slightly further in 2007.

There was agreement that structural reforms will need to span several areas to exploit synergies and balance the interests of different stakeholders. At the same time, prioritization within these areas is equally important to secure fast progress. In line with the authorities' emphasis on raising public awareness of the benefits of structural reforms, the upcoming 2007 elections provide an opportunity to place the country's economic priorities at the center of an informed public debate.

Fiscal adjustment remains high on the government's agenda. The objective of balancing the budget by 2010 through expenditure restraint is appropriate. The ongoing strengthening of fiscal governance will help in achieving this goal, provided it is underpinned by bold and specific political choices. The government's intention to curb social security and local authorities' spending growth is key. Tax reforms have increased the incentives to work and invest, but a further reduction in the tax burden is desirable and dependent on additional spending cuts.

Reforms in financial, labor, and product markets are necessary to boost job creation, prepare the economy for aging, and allow it to benefit fully from global activity. While the financial system is highly stable and supervisors are responding to evolving risks, the staff sees scope to improve its efficiency by phasing out administered schemes and accelerating financial integration in Europe. In the labor market, there is increasing recognition of the need to reduce the judicial uncertainty surrounding permanent labor contracts; in contrast, the chances of consensus on a widening of the differentials among the median wage, the minimum wage, and out-of-work benefits remain remote. In product markets, deregulation of the services sector and an acceleration of the ongoing disengagement of the state from commercial activities would boost growth and consumer welfare. 


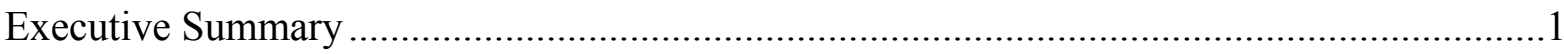

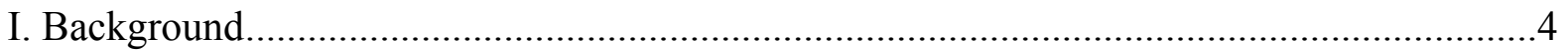

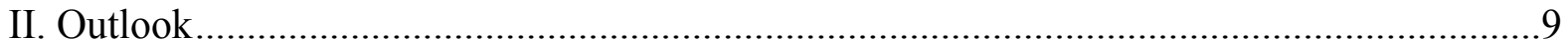

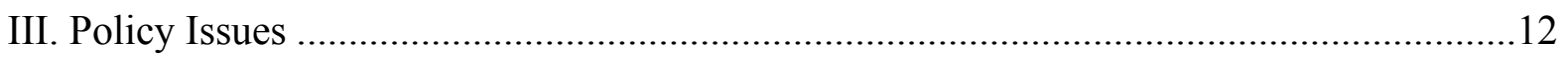

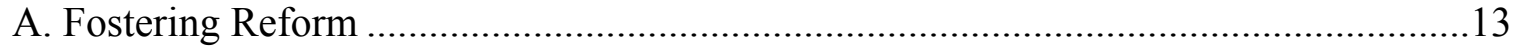

B. Achieving Fiscal Sustainability and Efficient Taxes .............................................15

C. Combining Financial Sector Stability and Efficiency.............................................18

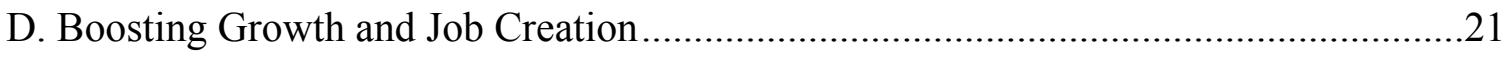

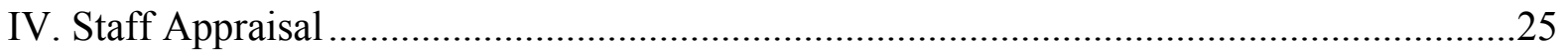

Figures

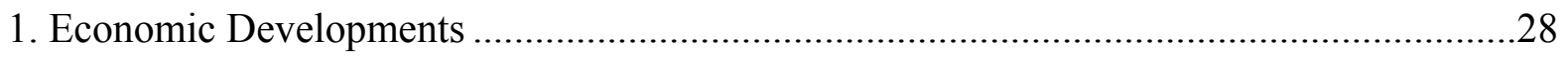

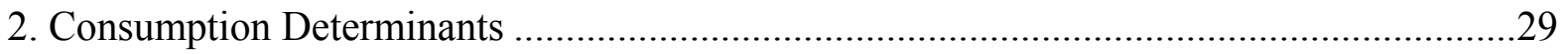

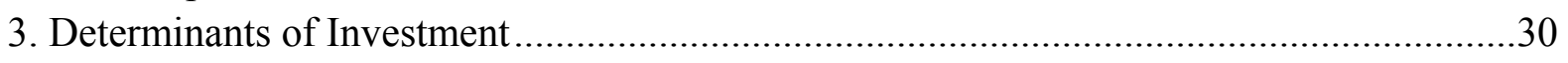

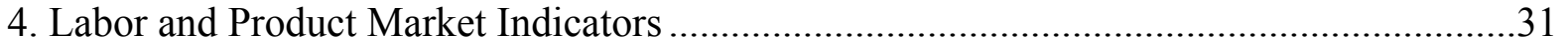

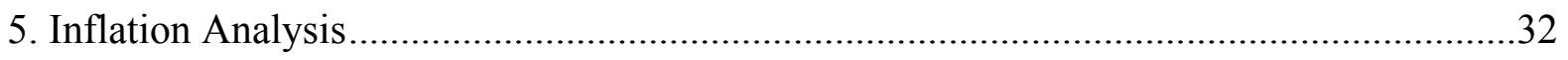

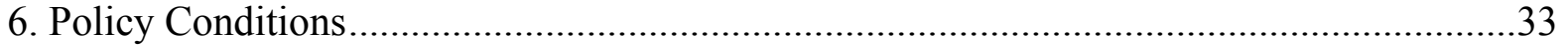

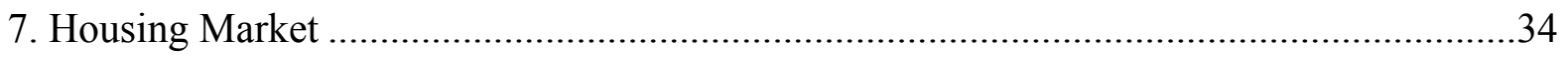

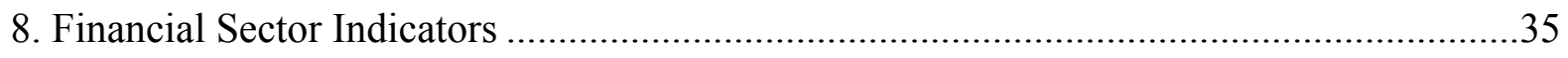

Tables

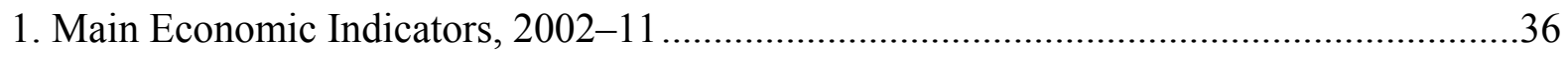

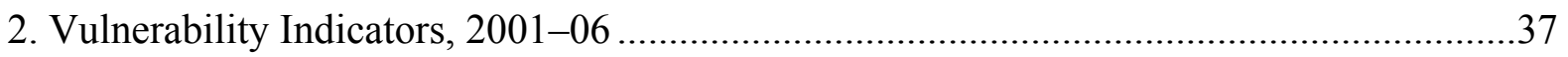

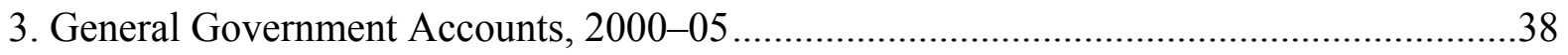

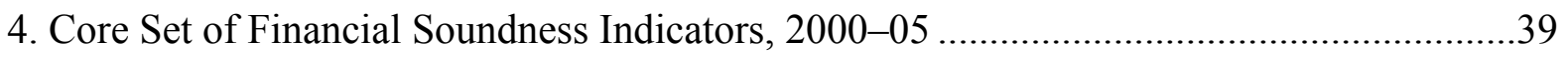

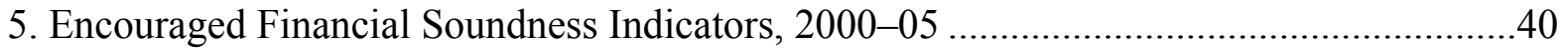

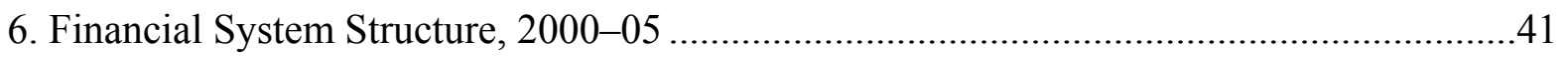

\section{Text Boxes}

1. External Performance_-Demand, Competitiveness, and Structural Factors .......................6

2. Economic Performance and Policies in International Perspective .................................. 10

3. Implementation of Fund Recommendations ....................................................... 14

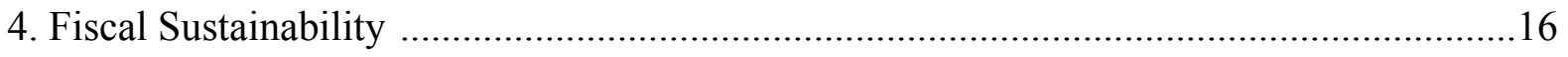

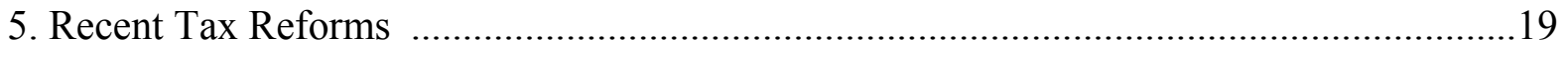

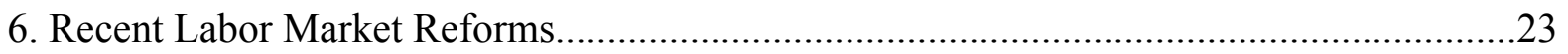




\section{Appendices}

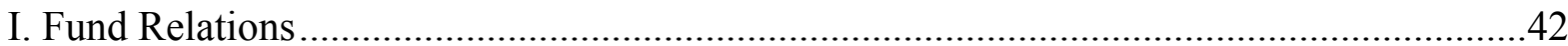

II. Statistical Issues and Table of Common Indicators 


\section{BACKGROUND ${ }^{1}$}

1. Against the backdrop of a cyclical upswing, the economic policy debate is focusing on how to foster the structural reforms necessary to reduce unemployment, address population aging, and allow the economy to benefit fully from dynamic global activity. In a departure from an approach that observers have characterized as "reform by stealth," the government has in recent years placed increasing emphasis on educating the public about economic choices. This approach has met with success in the area of public finance where the need for curbing spending, debt, and deficits is generally well understood and where pension and health care reforms are advancing. The main challenge now is to convince the public of the benefits of a much more flexible labor market and of further reforms in services and product markets. The 2007 elections provide an opportunity to advance the public debate on these issues.

\section{After stagnating in the first half of 2005 , economic activity regained considerable} momentum, but it remains behind the ongoing global expansion. Driven by domestic demand and a rekindling of exports, GDP growth picked up to a remarkable $43 / 4$ percent (annualized) in the second quarter of 2006 (Figure 1 and Table 1). This uptick was shared across the euro area as demand in Germany and Italy strengthened, joining robust domestic demand in other euro area countries. It permitted French exports to rebound strongly following three years of weakness compared to buoyant global demand. From a longer-term perspective, though, France's relative performance has lagged, prompting it to fall in the per capita GDP ranking (adjusted for purchasing power) from $12^{\text {th }}$ to $16^{\text {th }}$ position during the past five years.

3. All components of domestic demand contributed to the upswing. Household consumption and investment in housing have remained solid, helped by falling unemployment, real increases in the minimum wage (SMIC), and low interest rates (Figure 2). Still, health reform-induced increases in social security contributions and higher income taxes curbed disposable income growth, prompting households to dip into their savings (Table 2). Fixed capital formation strengthened with the revived cyclical upturn (Figure 3). Profit margins have declined since 2003 as moderation in wage growth was insufficient to offset the impact of higher input prices, while generous dividend payouts and higher tax obligations reduced company savings. Low interest rates encouraged external financing, resulting in a declining self-financing ratio and rising debt, thus ending a four-year period of balance-sheet adjustment (Text Figure).

\footnotetext{
${ }^{1}$ Mission details are included in Appendix I (Fund Relations), and statistical information is in Appendix II.
} 
Savings and Investment, Nonfinancial Business

(In percent)

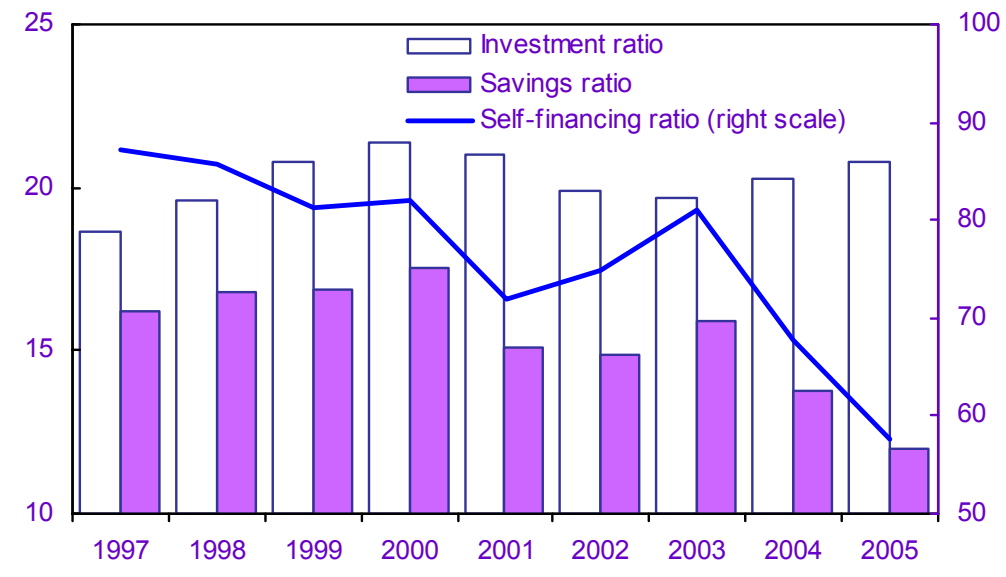

4. Despite the strong rebound of exports since mid-2005, concerns about competitiveness have not disappeared, mainly because structural factors seem to hamper export performance. The external sector subtracted between 0.7-1 percent from annual growth in

2003-05, and - together with adverse termsof-trade effects-led to a shift in the current account into a deficit of about 1.5 percentage points of GDP. However, export volumes have perked up markedly since mid-2005, in line with the rebound in partner demand (Text

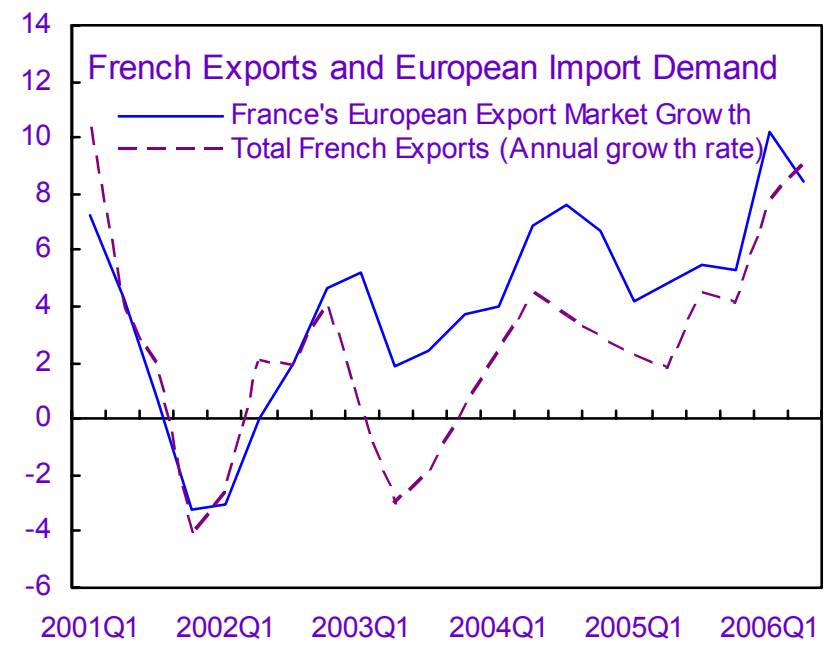

Figure), and the foreign balance contributed positively to growth in the first half of 2006. The prior weakness of manufactured goods exports seems to reflect structural issues (Box 1). France's cyclical position has not been far ahead of that of its main trading partners, its real effective exchange rate has changed little, and the exchange rate is estimated to be broadly in line with fundamentals. Geographical and sectoral compositions of trade have only limited explanatory power. The authorities and the staff agreed that structural rigidities in product and labor markets - in the staff's view including high minimum wages - were important explanatory factors as they reduced the economy's ability to rapidly adjust to developments in trade partners and take advantage of robust global growth.

\section{The pace of job creation, while picking up, has been hampered by sustained real} minimum wage increases, and participation remains low. Strong activity in the nontradable sector supported labor demand, while the secular decline in manufacturing employment was exacerbated by rising wage costs. Labor market reforms (such as the new contract for small enterprises $(C N E)$ and reinforced job search requirements and employment 


\section{Box 1. France: External Performance-Demand, Competitiveness, and Structural Factors}

Developments in exchange rates, relative unit labor costs, and demand are insufficient to explain the recent decline in the current account and France's export market share. Indeed, residuals from econometrically-estimated equations indicate a substantial drag on exports since 2001, not attributable to the standard global demand and price/cost factors (Figures A and B). ${ }^{1}$ However, the buoyant trade of the first half of 2006 is not reflected in this analysis, though it seems mostly related to the upswing in the euro area. Geographically, trade with Germany and China contributed most to the deterioration in the manufacturing trade account. At the sectoral level, exports of automobiles and intermediate goods slumped, but investment and consumer goods exports held up well. Strong import growth was partly due to more dynamic investment than in other European countries (Figures C and D). Finally, oil price increases caused a considerable rise in the import bill.

Standard equilibrium exchange rate analysis indicates that the current real effective exchange rate is largely in line with fundamentals. Multilateral analysis conducted by the IMF's Research Department suggests that the real exchange rate does not significantly deviate from equilibrium based on saving-investment balances (less than 5 percent) and is essentially in equilibrium using the methodology calculating purchasing power parities. These findings are subject to considerable uncertainty, however.

In this context, it is important to note that changes in export margins have cushioned the effects of exchange rate fluctuations. Cost competitiveness of French producers worsened in 2005 and early 2006, though it remains in line with its long-term average (Figure E). Price competitiveness was maintained as producers lowered export prices in euro (Figure F). This behavior is indicative of the limited pricing power of exporters in increasingly competitive markets. Moreover, despite such pricingto-market, the external position deteriorated during the period.

Hence, the relative underperformance of exports in past years points to structural factors that leave French firms behind the global expansion. A more flexible economy should be able to reorient its geographical orientation and product mix toward fast-growing economies and sectors. Indeed, the staff finds evidence that labor market rigidities hamper such adjustment. A sectoral study of total factor productivity (TFP) growth in manufacturing finds that, while France does not lag significantly behind the United States in terms of level, its TFP growth is hampered by the high ratio of minimum to median wages. ${ }^{2}$ In this observation, the staff's analysis is joined by a KPMG study that finds that the high cost of low-skilled workers constituted France's main disadvantage in reference to other G-7 countries. The staff's study further shows that more spending on R\&D and more trade with technologically advanced countries tends to positively influence TFP growth.

\footnotetext{
${ }^{1}$ Export equations (see IMF Country Report No 05/401) have been re-estimated using the new rebased dataset from INSEE and additional data for 2005.

${ }^{2}$ Khan, Tehmina, "Productivity Growth, Technological Convergence, R\&D, Trade and Labour Markets: Panel Data Evidence from the French Manufacturing Sector,” IMF WP, forthcoming.
} 


\section{Box 1. France: External Performance-Demand, Competitiveness, and Structural Factors (concluded)}
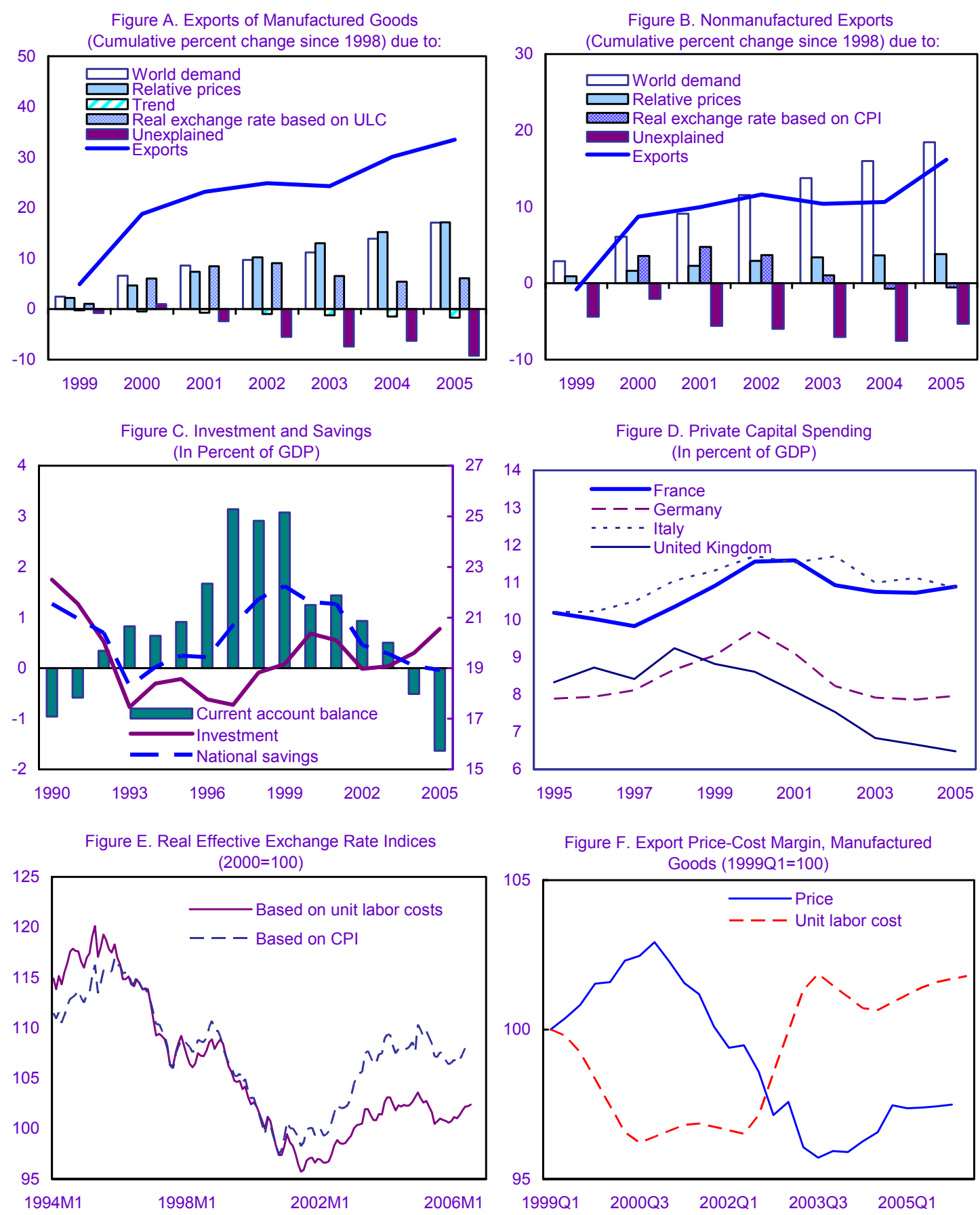

Figure F. Export Price-Cost Margin, Manufactured

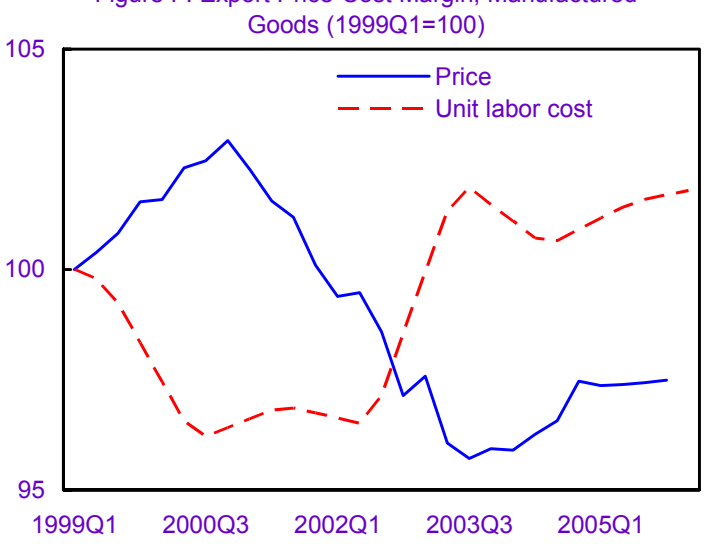

Sources: INSEE; and IMF staff estimates. 
services) have helped job creation, but they have not yet undone the adverse effect of high (and, on the OECD's measurement, rising) employment protection and the workweek reduction. Government-aided jobs, which were being phased out during 2004-05, are staging a comeback, contributing again to employment growth. Conversely, minimum wage increases are exerting a drag, keeping the pace of job creation well below that of previous recoveries (Text Figure). ${ }^{2}$ Hence, while the overall

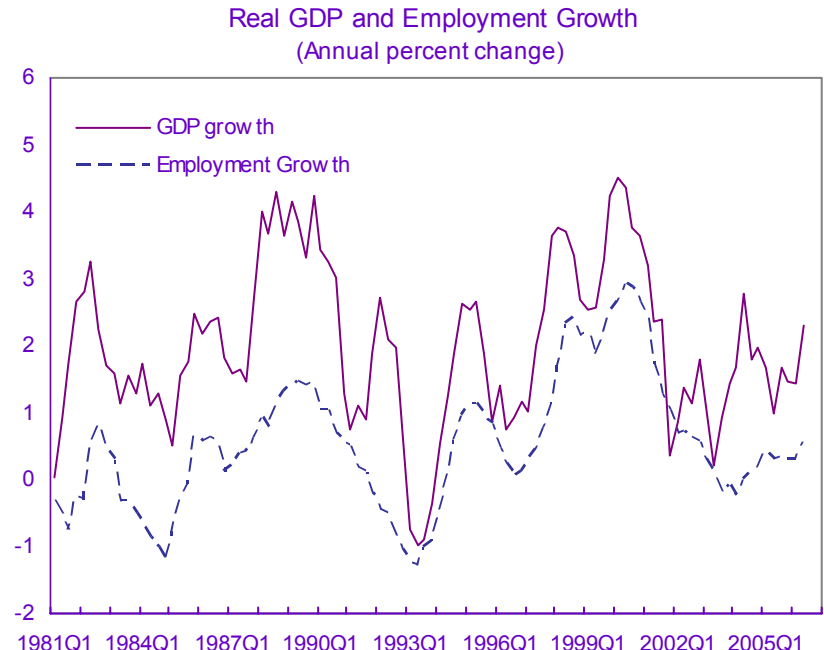
unemployment rate has been declining, its structural component has fallen much less (Figure 4). With pension reforms allowing people to retire on the basis of career length rather than age, many have taken the opportunity to retire early, while the effect of introducing an actuarially fairer system is expected to play in the opposite direction only over time. ${ }^{3}$

\section{Energy prices have kept headline inflation up through the middle of 2006, while} underlying inflation has been well-behaved. Core and headline inflation declined to slightly below the euro area average as the effect of a previous tobacco excise tax hike evaporated in mid-2005. Factors other than oil prices, in particular strong international competition in manufactured goods and the liberalization of distribution margins, had on balance a dampening impact on inflation. Rents edged up, as they are legally tied to the construction price index, ${ }^{4}$ which was pulled by a strong housing market. Services provided by unskilled labor imparted slight cost-push pressures, reflecting higher minimum wages. Economy-wide unit labor costs have risen somewhat, in part because of a cyclical decline in productivity growth (Figure 5).

\footnotetext{
${ }^{2}$ A counterfactual simulation suggests that employment growth would have been $1 \frac{1}{4}$ percent higher during the past five years, had minimum wages not increased. The real increase of the SMIC during this period amounted to 15.2 percent.

${ }^{3}$ A normal pension vests after a career of 40 years, a duration that is being increased gradually to 41 years by 2012. Earlier retirement is possible at an actuarially fair discount. However, working longer yields a lessthan actuarially fair bonus. The parameters of the pension system are subject to 5 -year reviews, with the next due in 2008 .

${ }^{4}$ Since January 2006, rents have been tied to a basket of prices comprising construction costs (with a 20 percent weight), consumer price inflation ( 60 percent), and maintenance costs (20 percent).
} 
7. Despite fiscal tightening, overall, policies have been supportive of growth (Figure 6). Monetary conditions remain accommodative as increases in real interest rates were partly offset by the depreciation of the real effective exchange rate, at least until very recently. The structural fiscal deficit decreased by about $3 / 4$ of 1 percentage point of GDP in 2005 and is likely to continue to fall, but by somewhat less than $1 / 2$ of 1 percentage point in 2006 (Table 3). This fiscal tightening had only limited impact on growth as private domestic demand continued to outpace GDP.

8. By regional comparison, the economy has been performing well, but several structural weaknesses stand out, and progress in tackling them has been mixed (Box 2). GDP per capita is high, and growth per capita has been exceeding the euro area average, though the difference seems to be evaporating. Globally, France's relative position has deteriorated substantially, particularly as it failed to keep up with the United States. Pension reforms have limited the increase in age-related spending (excluding long-term care) to 2.9 percent of GDP between 2004 and 2050, compared to an EU average of 4 percent (according to the EC Aging Working Group), but its level (12.8 percent of GDP in 2004) will remain above the EU average (10.6 percent of GDP), and public debt has risen (to some 67 percent of GDP). Labor markets have become more flexible, though employment protection has increased, and taxes, unemployment benefits, and minimum wages are high. Consequently, employment rates have improved much less than elsewhere.

\section{OUTLOOK}

9. Near-term growth is expected to remain solid, somewhat stronger than anticipated at the time of the mission. The staff projects GDP growth to remain broadbased and settle at an annual pace of about 2.5 percent during the second half of 2006 , yielding average growth of 2.4 percent for the year. In 2007, higher oil prices and interest rates and lower trade partner growth will reduce growth slightly to about 2.3 percent. In particular, the staff does not expect households to further reduce their savings rate from current levels and sees residential construction growth slowing. The unemployment rate should decline, reflecting healthy growth, increased subsidized job creation, and the impact of pension and labor market reforms. In line with surveys, business investment is likely to keep expanding firmly while export growth should ease somewhat from its recent buoyant pace. While expressing some concerns about the impact on the outlook of fiscal reforms and adjustment planned in Germany, the authorities expect that the economic impact on France was likely to be small.

\section{Risks to this baseline are broadly balanced and related to external shocks and}

the impact of ongoing structural reforms (Text Figure). Staff analysis suggests that France has become more sensitive to the global economy and reacts more through changes in employment and productivity than through wage flexibility, strengthening the case for more 
Box 2. France: Economic Performance and Policies in International Perspective
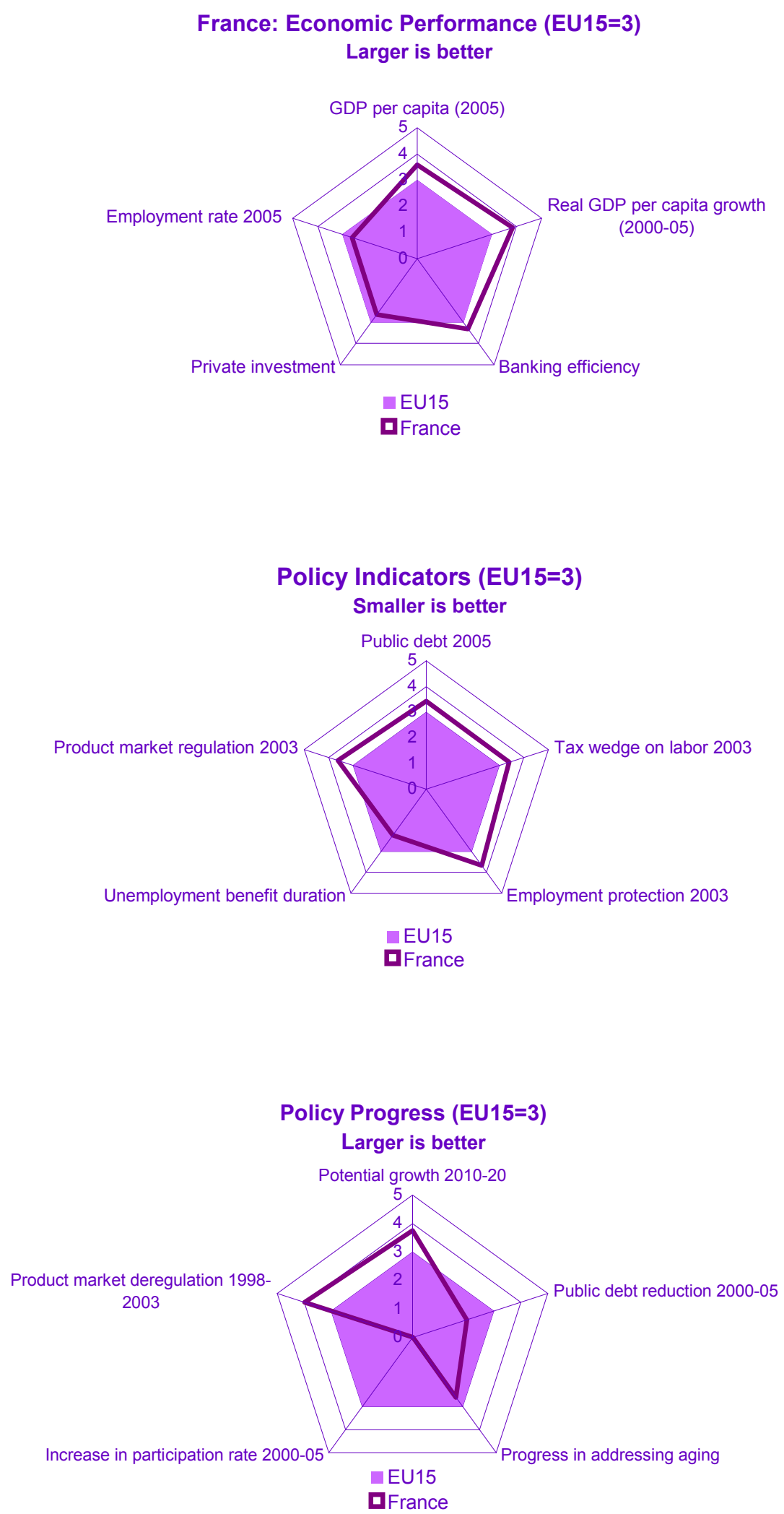
structural reforms. ${ }^{5}$ The authorities and the staff concurred that recent structural reforms had likely increased potential growth (see $\$ 13$ ), but the timing of their effect on actual growth was hard to pin down. The elections, scheduled for the second quarter of 2007, constitute some source of uncertainty about the future course of economic policies.

\section{Real GDP Growth: Risks to the Forecast}

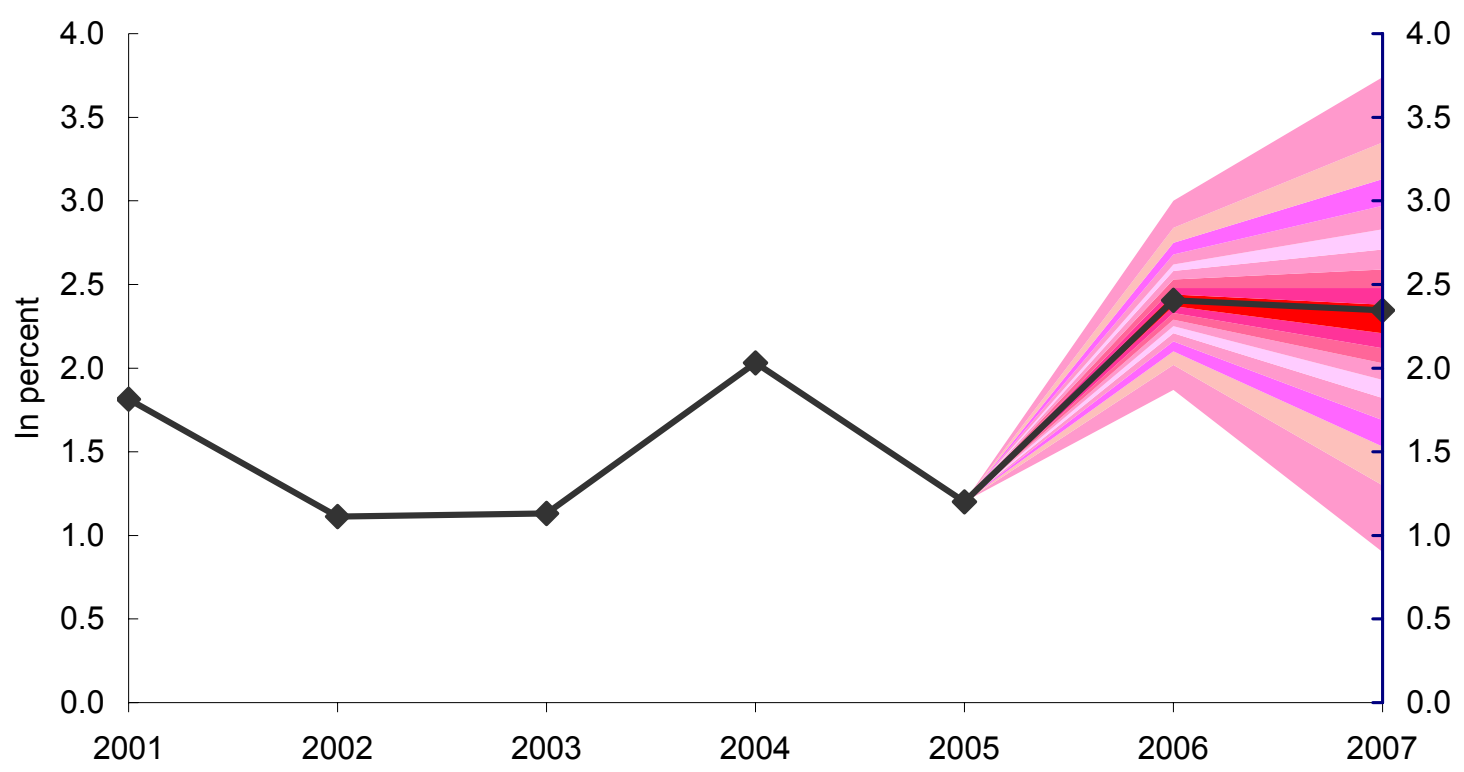

The fan chart includes the following risks to the baseline projections of growth (2.4 percent in 2006 and 2.3 percent in 2007): a 15 percent euro appreciation, a 20 percent increase in oil prices, a 1 percent higher trading partners growth, a 1 percent lower household saving ratio, an avian flu pandemic and a disorderly unwinding of global imbalances. They are weighted by the staff's subjective probability assessment of their occurrence.

11. After five years of strong increases, house prices show signs of cooling, which represents a small risk to the economy (Figure 7). Construction activity is expected to slow in line with the market for existing houses. The authorities and the staff agreed that there was no evidence of any significant impact of housing wealth on consumption. ${ }^{6}$ The real estate boom was accompanied by strong credit expansion to households, though the authorities saw only limited risks to financial sector stability, as house prices have been largely in line with fundamentals, household indebtedness has remained low by international comparison, and equity withdrawal has hitherto been absent (see $q 28$ ).

\footnotetext{
${ }^{5}$ See Selected Issues Chapter I: "France in the Global Economy."

${ }^{6}$ For an econometric evaluation, see IMF Country Report No. 04/246, November, "Household Consumption in France."
} 
12. The authorities favored a coordinated effort to ensure an orderly resolution of global imbalances, which remained a risk to sustained growth in Europe. They agreed that the main role for Europe would be to proceed with structural reforms to raise growth. At the same time, they cautioned against policies that would import the imbalances into the euro area, for example by creating an excessive current account deficit for the area. They also underscored the need to strengthen economic policy governance and policy coordination at the EU level.

13. Headline inflation is expected to average about 2 percent for the next few years. This projection implies a slowing from 2.2 percent in July 2006 as the pace of oil price increases eases. Conversely, underlying inflation - at 1.3 percent in July 2006-is expected to edge up gradually, as the effect of the reforms that led to a decline in distribution prices in 2005 wanes and the room to offset minimum wage increases by further cuts in social security contributions is being exhausted. Upside risks pertain to health care costs, discretionary minimum wage increases, and oil prices, while additional structural reforms could have a dampening effect.

\section{Current demographic trends and ongoing structural reforms suggest that} potential growth could be higher than previously estimated. Recently-observed fertility rates and immigration suggest that the labor force, previously expected to begin to fall in 2007, will continue to grow into the next decade. At the same time, higher-than-expected female mortality signals a slower rise in the dependency rate, slightly easing the increase in aging costs from previous projections. The authorities estimate that the pipeline effects of structural reforms could add $0.1-0.2$ percent to potential growth over the medium term and see some evidence that the secular decline in total factor productivity growth has ended. Together with the effects of the recent uptick in investment, this suggests that annual potential growth could temporarily rise to $2 \frac{1}{4}-2 \frac{1}{2}$ percent, before - in the absence of further reforms - settling at somewhat less than 2 percent per year in the long run. On the basis of this information, the staff has revised its annual potential growth projections up from 1.9 percent to 2.2 percent for the next five years.

\section{Policy Issues}

\section{Achieving fiscal sustainability, full employment, and higher trend growth} remain priority objectives for economic policy. ${ }^{7}$ Reflecting greater public consensus, fiscal adjustment has been progressing faster than expected, and institutional mechanisms have been put in place to secure further progress. Nonetheless, the ongoing cyclical upswing and the upcoming 2007 elections will test both this consensus and these mechanisms. At the same time, the electoral debate provides an opportunity to seek the public's endorsement of

\footnotetext{
${ }^{7}$ The staff's analytical work has had a long-standing focus on these issues (see Selected Issues Annex for an overview since 2000).
} 
broader and faster structural reforms, particularly in the labor market, much needed to prepare the economy for aging and allow it to benefit from globalization (Box 3). Hence, while no major new reforms will be tabled, the authorities plan to continue implementing ongoing reforms during the preelection period aimed at reducing the budget deficit and creating jobs, especially for the young. More broadly, they intend to foster debate and consensus on the causes and remedies of high unemployment.

\section{A. Fostering Reform}

16. The authorities underscored the importance of economic pedagogy and building consensus to promote structural reform. They pointed to the success of this approach in a number of areas, based on studies and stakeholder committees. For example, efforts at fiscal consolidation had benefited from a number of reports, most recently the Pébéreau report on the worrisome level of public debt. In parallel, an annual national conference on public finances involving all levels of government and a new council on public finances (Cofipu), with among its mandates the promotion of expenditure restraint, had been established. As a result, the need for a reduction in public debt and deficits was now widely recognized. Hence, attention is being focused on the pace of consolidation and the distribution of the effort among levels of government. A key issue was now to further build credibility by continuing to meet the spending and deficit targets as had happened for the first time in 2005.

17. Given the public's high sensitivities, reforms would need to be approached very cautiously in the labor market. The authorities saw the social unrest in reaction to the proposed new labor contract for the young $(C P E)$ and its subsequent withdrawal as an indirect confirmation of the need to follow a gradual, consensual approach. Indeed, while the measure was intended to rapidly improve job prospects for urban unemployed youth, stakeholders had not been consulted sufficiently, and prior consensus had not been achieved. Partly in response, a new council on employment $(C O E)$ had been created to establish a common diagnosis of the causes of unemployment among social partners and foster public debate on its remedies.

\section{The authorities stressed the need to sustain income growth at a time of} structural reform. They noted that they had accordingly balanced fiscal adjustment and pension and health care reforms with increases in the minimum wage and benefits (including the earned income tax credit), greater opportunities for workers to participate in profits, better prospects and financial incentives for working longer, improved access to credit, tax cuts, and measures to prevent income loss for health care providers.

19. The staff recognized the benefits of the authorities' approach, while suggesting some adjustments to ensure faster progress. Reforms seem to have met with success when 


\section{Box 3. France: Implementation of Fund Recommendations}

The authorities have concurred broadly with the direction of the Fund's economic policy advice, but implementation has been more gradual and subject to more tradeoffs in order to preserve social cohesion, generous welfare arrangements, and a narrow income distribution.

Fiscal policy: Budgetary execution over the past three years has been in line with long-standing Fund advice to consolidate by at least 0.5 percent of GDP annually until structural balance or surplus is achieved. The pension reform has appreciably diminished the projected cost of aging, health care reform is progressing, and civil service reform is picking up but remains more modest than advocated by the Fund. Revenue windfalls are now being fully saved, and fiscal governance has been strengthened considerably.

Labor and product markets: Additional flexibility was introduced in labor markets, especially reversing some of the restrictions related to the reduction of the workweek to 35 hours. The new employment contract (CNE) represents an important step in reforming labor market institutions, but entitlements (other than pensions), judicial uncertainty surrounding labor contracts, and high minimum wages remain to be tackled. In product markets, divestiture and deregulation are ongoing, albeit at a slower-than-advised pace, and there is scope for further liberalization of trade in services.

Financial sector: The financial sector has been subject to strong supervision. The authorities continue to be reluctant to phase out widespread administrative deposit and loan schemes, though some of them have become more market-oriented.

Trade policy: The Fund has called on France to help advance trade liberalization, partly through an early implementation of Common Agricultural Policy (CAP) reform. The authorities indicated their commitment to a successful conclusion of the Doha round and noted that accelerating CAP reform, planned for 2007, would have disrupted farmers' preparations.

they were accompanied by highly visible quantitative objectives, e.g., the expenditure norms for the central government and health care. This approach could usefully be extended to other areas of public finance and to structural reforms as well, for instance by focusing on employment rates for labor market reforms, and product market regulation indicators for reforms in product markets. At the same time, efforts of various councils, useful in advancing a comprehensive understanding by stakeholders, would need to be well coordinated to exploit synergies, particularly in dealing with distinct entrenched interests. While trade-offs are inevitable, significant dilution of the long-term gains should be avoided. It will also be 
important to apply the pedagogic approach consistently. For example, "economic patriotism" may sound attractive to some, but it has a protectionist guise that runs counter to France's best interests.

\section{B. Achieving Fiscal Sustainability and Efficient Taxes}

20. Rising costs of aging and high deficits constitute the main threats to fiscal sustainability. While pension reforms and the improved outlook for potential growth have significantly reduced the expected increase in the cost of aging, current policies would still lead to unstable debt dynamics (Box 4). There was agreement that further growth-enhancing structural reforms and fiscal adjustment would be needed and that more of the former would facilitate the latter. Health care costs, while better contained than in the past, will continue to pressure the budget, rendering additional measures inevitable. The general government deficit is still too high to stabilize public debt. The decline in the debt ratio in the course of 2006 is due to asset sales and tighter cash and debt management.

21. Over the past three years, fiscal consolidation has progressed significantly, while fiscal governance and spending restraint have been strengthened. Between 2003 and 2006, the structural deficit has been reduced by more than $1 \frac{1}{2}$ percent of GDP (Text Table). The authorities highlighted that France had been the first of the large euro area countries under the excessive deficit procedure to have brought the deficit to less than 3 percent of GDP in 2005 (albeit with the help of a one-off transfer from the electricity sector against its future pension liabilities); real central government spending had been constant for four consecutive years; health care spending had been on target in 2005 for the first time in recent history; and the pace of reduction in the number of civil servants, while modest (only one out of every seven retiring civil servants is not being replaced), was being stepped up. Further, all revenue windfalls are being used to reduce the deficit, a feature embedded in the 2006 budget law, and expenditure margins are being set aside ex ante. The implementation of the new organic budget law is fostering a results-oriented culture in the civil service. Finally, independent budget oversight by the Cour des Comptes had been strengthened, including via more ex ante analysis, though it was felt that it should better focus on the general government.

22. Nevertheless, continued growth of social security and local government spending has prevented the expenditure-to-GDP ratio from declining and required fiscal adjustment to rely on increased revenues. Public spending has been stuck at over 53 percent of GDP, with local and health care spending growing at about 4 percent per year during the past five years. Fiscal adjustment thus stemmed from higher revenues: two thirds 


\section{Box 4. France: Fiscal Sustainability}

In March 2006, the pension council (Conseil d'Orientation des Retraites, COR) revised estimates of the needs of the pension system by 2050 . The COR's projection, which did not incorporate the most recent revision to the demographic profile, pointed to an increase in budgetary costs of 3.1 percentage points of GDP after taking into account the impact of the 2003 pension reform (estimated to have lowered these costs by 1.2 percentage points of GDP). While providing detailed sensitivity analysis to changes in economic and demographic assumptions, as well as changes to policy parameters, the report highlights the need for further reform to guarantee the sustainability of the system.

\section{The staff analysis concurs with this} assessment. ${ }^{1}$ Despite the recent revisions to demographic projections pointing to more favorable population aging dynamics than in the COR baseline and the positive effect of the recent health care reforms, aging costs remain the key threat to fiscal sustainability. Under the staff's baseline scenario, they are expected to add 4.5 percentage points of GDP to fiscal spending by 2050 (2.7 percent for pension and 1.8 percent for health) leading to unsustainable debt dynamics.

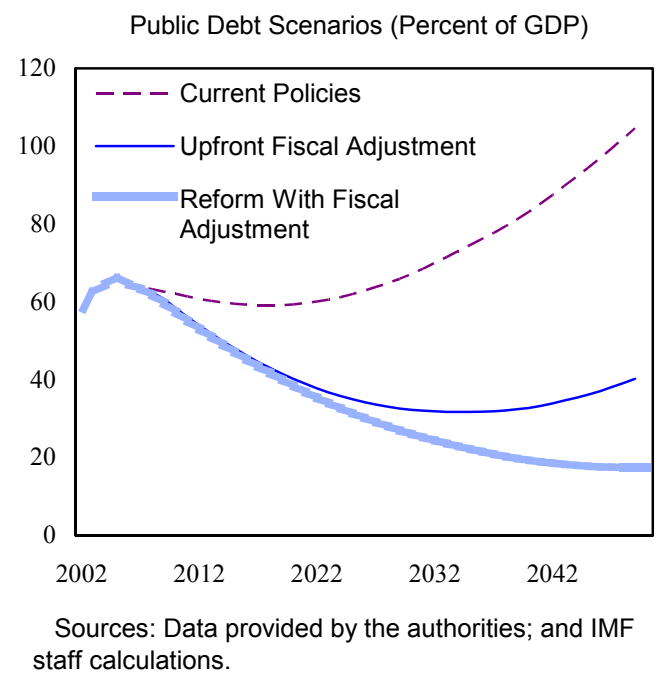

\section{Addressing the long-term costs of aging requires further fiscal consolidation} through a combination of fiscal adjustment and growth-enhancing measures. Upfront fiscal adjustment alone, consistent with the authorities' goal of reaching fiscal balance by 2010, would bring the debt-to-GDP ratio down to about 30 percent by 2030 but would not suffice to stabilize it. However, a reform scenario in line with a (delayed) Lisbon agenda (expected to boost potential growth by at least $1 / 4$ percent after 2012) together with an upfront structural fiscal adjustment of 0.3 percent of GDP per year through 2011 would achieve sustainability at a public debt-to-GDP ratio of about 20 percent of GDP by 2050 .

\footnotetext{
${ }^{1}$ The current policy scenario reflects fiscal policies as described in Table 1 through 2011. Demographic assumptions are consistent with INSEE's recent population projections with a fertility rate of 1.9 , life expectancy of men and women of 83.8 years and 89 years, respectively, and net migration of 100,000 per year, which compares favorably to previous assumptions of lower fertility (1.8), higher life expectancy $(+1.2$ years $)$ and lower migration $(50,000)$.
} 
Text Table. France: General Government, Current Policies, 2005-11

(In percent of GDP; unless otherwise indicated)

\begin{tabular}{|c|c|c|c|c|c|c|c|c|c|}
\hline & \multirow[b]{2}{*}{2005} & \multicolumn{6}{|c|}{ Staff Projection } & \multicolumn{2}{|c|}{ Average } \\
\hline & & 2006 & 2007 & 2008 & 2009 & 2010 & 2011 & 2002-06 & 2007-11 \\
\hline Revenue & 50.9 & 50.9 & 50.6 & 50.3 & 50.3 & 50.3 & 50.3 & 50.0 & 50.3 \\
\hline Tax revenue & 44.0 & 44.3 & 44.0 & 43.8 & 43.8 & 43.8 & 43.8 & 43.5 & 43.9 \\
\hline Nontax revenue 1/ & 6.9 & 6.6 & 6.5 & 6.4 & 6.4 & 6.4 & 6.4 & 6.5 & 6.5 \\
\hline Expenditures & 53.8 & 53.6 & 53.2 & 52.8 & 52.5 & 52.2 & 52.0 & 53.3 & 52.6 \\
\hline Real growth rate (in percent) 2/ & 2.3 & 1.9 & 1.4 & 1.7 & 1.7 & 1.8 & 1.8 & 2.1 & 1.7 \\
\hline Central government 2/ & 0.0 & 0.0 & -1.0 & 0.0 & 0.0 & 0.0 & 0.0 & 0.0 & -0.2 \\
\hline Social Security $2 /$ & 2.4 & 2.6 & 2.5 & 2.4 & 2.4 & 2.5 & 2.5 & 2.7 & 2.5 \\
\hline Health $2 /$ & 1.7 & 1.1 & 1.2 & 1.2 & 1.2 & 1.3 & 1.3 & 1.7 & 1.2 \\
\hline Local government 2/ & 3.5 & 3.1 & 2.8 & 2.8 & 2.7 & 2.7 & 2.7 & 4.2 & 2.7 \\
\hline Primary balance & -0.2 & -0.1 & -0.1 & -0.1 & 0.3 & 0.6 & 0.9 & -0.6 & 0.3 \\
\hline Overall balance $3 /$ & -2.9 & -2.7 & -2.6 & -2.5 & -2.2 & -2.0 & -1.7 & -3.3 & -2.2 \\
\hline Structural balance 3/ 4/ & -2.2 & -1.8 & -1.8 & -1.8 & -1.8 & -1.7 & -1.7 & -2.7 & -1.7 \\
\hline Gross debt 3/ & 66.6 & 64.4 & 63.9 & 63.4 & 62.8 & 62.2 & 61.4 & 63.2 & 62.7 \\
\hline \multicolumn{10}{|c|}{ Memorandum items: } \\
\hline \multicolumn{10}{|c|}{ Staff recommendation (Reform and adjustment) 5/ } \\
\hline Expenditures & 53.8 & 53.6 & 52.6 & 51.7 & 51.0 & 50.3 & 50.3 & 53.7 & 51.2 \\
\hline Primary balance & -0.2 & -0.1 & 0.5 & 1.0 & 1.8 & 2.4 & 2.4 & -0.6 & 1.6 \\
\hline Overall balance $3 /$ & -2.9 & -2.7 & -2.1 & -1.4 & -0.7 & 0.0 & 0.0 & -3.3 & -0.9 \\
\hline Structural balance 3/ 4/ & -2.2 & -1.8 & -1.3 & -0.8 & -0.3 & 0.2 & 0.0 & -2.7 & -0.4 \\
\hline Structural adjustment 4/ & 0.7 & 0.4 & 0.5 & 0.5 & 0.5 & 0.5 & -0.2 & 0.6 & 0.4 \\
\hline \multicolumn{10}{|l|}{ Authorities' scenario 6/ } \\
\hline Overall balance 3/ & -2.9 & -2.8 & -2.5 & -1.7 & -1.0 & 0.0 & $\ldots$ & -3.3 & -1.3 \\
\hline
\end{tabular}

Sources: INSEE; IMF staff calculations; and Budget Discussion June 2006 Report.

$1 /$ Net of contribution to the EU.

2/ Real growth (in percent) adjusted using CPI excluding tobacco prices.

3/ Maastricht definition.

4/ Data for 2005 exclude the EDF pension fund transfer (0.5 percent of GDP); in percent of potential GDP.

$5 /$ Scenario in line with a delayed Lisbon agenda expected to boost potential growth by $1 / 4$ over the long run.

6/ As indicated in the Budget Discussion June 2006 Report.

was due to underlying dynamics of the tax base and the fact that the tax elasticity with respect to GDP is slightly higher than one, which more than offset personal income tax cuts. The remainder resulted from increases in health care contributions, partly offset by declining social security contributions elsewhere in the context of policies designed to support labor demand.

\section{In response, plans for fiscal consolidation are being underpinned by ambitious} objectives for expenditure restraint, but specific policy choices remain to be made. The authorities aim to balance the budget by 2010. From 2007 onward, real spending at the central government level is set to decline by 1 percent per year, growth of social security spending will not exceed 1 percent in real terms, and local authorities are expected to gradually move toward keeping real spending constant. For 2007, there is a commitment on 
the central government's objective, but little or no structural adjustment. In addition, how spending objectives will be achieved for the other components of government, and beyond 2007, remains to be spelled out. ${ }^{8}$ Hence, the staff projects the structural balance to remain in a deficit of about $13 / 4$ percent of GDP.

\section{Tax reforms have been geared at promoting employment and investment, but} tax expenditure initiatives are proliferating (Box 5). The increase in the earned income tax credit, the introduction of a ceiling on tax payments as a share of current revenue (bouclier fiscal), and the reduction in marginal income tax rates in 2007 will boost labor supply across the skills range. A cap on a local tax on capital and the extension of exemptions for new investments until they are on stream will help investment. However, in response to tight spending limits, policy proposals are becoming increasingly focused on granting tax exemptions and tax credits. The authorities acknowledged the need to stem this tide, which could be done by prohibiting such measures from being introduced outside annual budget laws.

\section{Current proposals to reform the financing of social security would have little} economic impact. Mindful of the high cost of labor, further cuts in employers' social security contributions are being considered, to be financed by an increase in taxes on consumption or capital. At the technical level, the staff and the authorities agreed that, in France's institutional context, there are virtually no benefits from such a shift. ${ }^{9}$ Shifting to consumption taxes would allow a slight reduction in marginal tax rates, but because social benefits and the minimum wage are indexed to inflation and unions may demand compensation for the loss of purchasing power, there are no other gains. Shifting to capital may have short-term benefits but at the cost of less investment and less output in the long run. Rather than shifting the tax burden, the staff argued for financing the reform through additional expenditure cuts.

\section{Combining Financial Sector Stability and Efficiency}

\section{The financial sector appears sound and well placed to manage some potential}

vulnerabilities. The sector is highly capitalized and profitable, though a substantial part of the recent rise in profits is likely to be transitory, as it is linked to reintegration of past provisions, low ongoing provisioning, and rapid credit growth (Tables 4-6 and Figure 8). Following a period of rapid expansion of mortgage credit, lending is becoming more balanced as credit to the corporate sector has picked up, while the real estate market shows

\footnotetext{
${ }^{8}$ A supplement to this staff report will report on the specifics of the 2007 budget.

${ }^{9}$ See Selected Issues Chapter II: "Economic Impact of Welfare Financing Reform."
} 


\section{Box 5. France: Recent Tax Reforms}

One of the objectives of French fiscal policy in the past years has been to reduce the tax burden on labor, which is comparatively high. Employers' social security contributions constitute about 55 percent of the overall implicit tax rate on labor (ITR), whereas employees' contributions and personal income taxes account for 17 and 28 percent of the ITR, respectively. The reforms will have a budgetary cost of about $1 / 2$ of 1 percent of GDP in 2007.

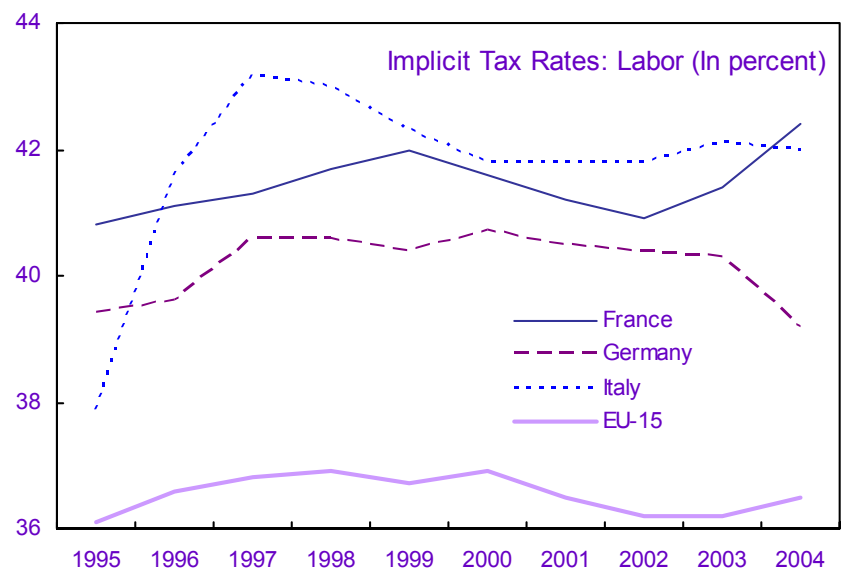

The government has recently enacted new measures to reduce taxes on labor income and make work pay:

- A personal income tax reform was introduced with the 2006 budget law and will take effect in 2007. The number of brackets was reduced from seven to five; headline tax rates were lowered, e.g., the top tax rate was cut from 48.09 to 40 percent; and a 20 percent existing exemption was eliminated and integrated into the new progressive structure. The reform aims at enhancing simplicity and equity, lowering the tax burden, and reducing high-skilled workers' incentives to move abroad.

- A tax ceiling was introduced, limiting total direct taxes to a maximum of 60 percent of income (bouclier fiscal). The taxes taken into account to compute such a ceiling include the personal income tax, certain real estate taxes on the primary residence, and the Impôt de Solidarité sur la Fortune (ISF), a tax on net wealth.

- The Prime pour l'Emploi (PPE), an income tax credit for people in low-paid jobs, was increased by 50 percent over two years for full-time workers, and almost doubled for part-time workers. The lag of credit disbursements was also shortened to increase work incentives.

The 2006 budget law also introduced a further reform of the taxe professionnelle, a local tax on capital. Its tax base originally comprised the wage bill and the rental value of the fixed capital stock, but to reduce the burden on labor, the wage bill was removed from the tax base. An exemption on new investment was introduced in 2004 to mitigate the tax impact on capital costs. The 2006 budget law made such exemption permanent and established a ceiling so that the tax cannot exceed 3.5 percent of the firm value added. 
some signs of cooling. The insurance sector is benefiting from the good stock market performance, rising interest rates, and the reduced incidence of natural disasters.

\section{The financial system has achieved a high degree of stability, and supervisors are} closely monitoring all risks. While under new accounting standards solvency ratios of French banks are lower (by about 60 basis points), solvency remains satisfactory. Heightened competition has prompted banks to relax loan standards somewhat and exploit less liquid market opportunities, while nonperforming loans and provisioning are currently at historically low levels and thus prone to a rise. In addition, exposure to emerging markets has increased. Nonetheless, stress tests indicate that banks could withstand a sharp increase in risk spreads and other shocks without much difficulty. ${ }^{10}$ Supervisors are focusing on exposure to hedge funds, which has remained limited, at no more than 3.5 percent of balance sheet totals. With respect to rising exposure to credit derivatives, they were reassured by banks' conducting specific stress tests to evaluate their value at risk.

\section{The establishment of a new bank and the introduction of new mortgage market} instruments are modifying the landscape of the financial sector. The emergence of the postal bank, which separates financial activities from the post office, is further leveling the playing field in the financial sector, though the new bank remains state-owned. To facilitate households' ability to manage wealth, real estate-backed credit lines and reverse mortgages have been introduced. Staff analysis indeed suggests that consumption in France is excessively sensitive to current income, which may be due to constrained access to financial markets. ${ }^{11}$ However, the new instruments are unlikely to constitute a significant breakthrough. Their uptake will depend on further reductions in legal requirements for collateralized lending. The real estate-backed credit line requires repayments before new credit can be obtained and is capped at the initial nominal loan amount, even if there are substantial capital gains in the meantime. The authorities motivated their cautious approach with the concern to avoid financial or macroeconomic instability.

29. The staff saw scope to enhance the financial sector's contribution to growth. It acknowledged the fierce competition for new customers, leading to mortgage products being offered at unprofitably low interest rates, but observed that switching costs for existing customers were very high and that elevated profits coincided with relatively high operating costs. The staff noted that pervasive administered deposit and savings schemes limited the scope for competition on the banks' liability side. The authorities saw little adverse impact from these schemes and had no plans to phase them out. They felt that the banking sector

\footnotetext{
${ }^{10}$ Shocks to the yield curve (shift up by 200 basis points, short rates up 200 plus long rates up 100 basis points), foreign demand (down 20 percent), house prices (40 percent decline in two years) would each reduce solvency (Basel II definition) by less than 1 percentage point.

${ }^{11}$ See Selected Issues Chapter III: ’Liquidity Constraints and Mortgage Market Reform in France."
} 
was highly competitive and noted their efforts to increase competition further at the retail level by requiring more transparent display of costs of services to customers. In addition, the launch of an Institute for the Financial Education of the Public was designed to help advance financial literacy.

30. The authorities supported further integration of financial markets in Europe, acknowledging the staff's call to accelerate this process. The staff, referring to studies suggesting an appreciable growth dividend from complete integration of Europe's financial markets, urged the authorities to swiftly establish standardized financial products and documentation and underwriting practices. It pointed to the potential for cost savings from integrating payments, clearing and settlement systems and harmonizing regulatory and supervisory practices for institutions who are increasingly operating across borders.

\section{Boosting Growth and Job Creation}

31. In recent years, structural reforms have transformed the economy more than is commonly perceived, but much remains to be done. The breakup of public utilities, the pension and health care reforms, and the introduction of a new labor market contract are some pertinent examples of progress. The authorities noted that, on the basis of the OECD's product market regulation indicators, recent reforms are likely to boost annual growth by 0.1-0.2 percent over the medium term. They agreed that much more remained to be done, particularly regarding employment rules, social security, and the services sector. They concurred that there was a case for simultaneous product and labor market reforms and for a better coordination of the timing of reforms in the EU. While they saw limited scope for new initiatives ahead of the 2007 election, they would persevere with the implementation of already adopted reforms.

\section{There is broad agreement on what is ailing the labor market. Laying off} employees on permanent contracts is very costly. Direct financial costs are not exorbitant, but firms must follow cumbersome and lengthy legal procedures and bear the burden of proof to justify dismissals, with judges ultimately deciding on their validity and cost. For example, layoffs for economic reasons can be justified on the basis of the desire to "preserve" but not to "improve" profitability or competitiveness, requiring courts to make business judgments for which they are not equipped. Consequently, to respond to economic developments, employers count on a substantial share of fixed-term and temporary workers, which can be dismissed at known costs. As a result, a dual labor market has emerged with a large segment of precarious jobs, explaining the coexistence of strong employment protection and the pervasive feeling of job insecurity. In addition, high minimum wages have been pricing lowskilled workers out of jobs, while generous benefits have been reducing job search incentives. The employment rate of older workers remains very low, owing to special early retirement regimes and rigid tenure-related pay scales.

33. Efforts are under way to change labor market institutions. The authorities emphasized that considerable progress had been made, with tax and pension reforms and the 
loosening of the restrictions of the 35-hour workweek promoting labor supply, the streamlining of employment services and tightening of job search requirements increasing the chances of successful job matches, and the new labor contract for small enterprises $(C N E)$ facilitating hiring (Box 6). Its extension to all young workers, aged 26 or less (CPE), had to be abandoned, however, in the face of social unrest. Eager to show results in terms of job creation, subsidized employment programs are being ramped up again after their decline in 2004-05. Together with earlier programs to reduce the cost of labor, the total budgetary burden of labor market policies is estimated to amount to 2.4 percent of GDP in 2006.

\section{The authorities agreed on the need to reinvigorate labor market reform.}

Essential will be the reduction of employment protection of permanent contracts, in particular the uncertainty surrounding the cost of terminating such contracts. Work had started on a streamlining of the labor code to diminish the latter. Moreover, the public debate on this issue appears to be advancing sufficiently to be able to move after the 2007 elections. However, while it was recognized that social benefits and minimum wages were too high compared to the median wage, the chances of achieving consensus on reform in this area seemed remote. ${ }^{12}$ The staff suggested that the minimum wage should henceforth be tied to the core index of inflation only. It also argued for a complete phasing-out of special early retirement regimes and of the exemption from job search for older workers, and for a further increase in the actuarial fairness of the regular pension system. The authorities responded that they would implement a package of measures to promote activity for older workers.

\section{Additional progress in product and services market reform will boost potential} output and consumer welfare. As observed with the reform of the distribution sector and the action of the competition authority in the case of collusion in the telecommunications sector, consumers stand to benefit greatly from increased competition. To further enhance these benefits, the staff called for replacing administrative approval of retail outlet locations by zoning requirements as recommended by the OECD. It also supported other key OECD recommendations, such as the liberalization of shop opening hours and sales periods and shortening and simplification of administrative procedures, especially for startups. The swift adoption of the EU services directive would also have benefits.

\footnotetext{
${ }^{12}$ The minimum wage is indexed to the mean of headline inflation and average wages of the previous year.
} 


\section{Box 6. France: Recent Labor Market Reforms}

In recent years, the authorities have implemented a series of initiatives to improve labor market performance. The strategy has focused on introducing gradual changes to existing labor market institutions and improving the efficiency of government-supported programs to increase labor demand while raising incentives to work. Beyond the 2003 pension reform, which should raise participation of older workers, key measures included:

- $\quad$ The relaxation of the 35-hour workweek legislation: The increase in the overtime quota, the end of restrictions on the use of time savings accounts, the reduction in the cost of overtime, and the added flexibility to negotiate work arrangements at the firm level have significantly eased work time constraints, especially for small firms, helping to boost working hours.

- The 2004 reform of collective bargaining: The reform increased the employers' ability to negotiate with unions and other labor organizations at the firm level, in particular with regard to hours worked, thus contributing to increasing flexibility of the 35-hour workweek. The legislation also introduced a majority principle for collective agreements to improve workers' representation in collective agreements.

- $\quad$ The streamlining of employment services and government-aided job programs with the implementation of the Plan de cohésion sociale (PCS): The PCS has sought to improve the efficiency of employment services by reducing job-search costs and strengthening compliance of job search requirements (including the obligation of active job search and training and the possibility of reducing unemployment benefits). By refocusing and simplifying government-aided job programs, the PCS has also helped raising labor demand, especially for the young and long-term unemployed, albeit adding to budgetary costs.

- $\quad$ The introduction of a new employment contract for small enterprises (CNE) in August 2005: The $C N E$ is a contract with a trial period of up to two years for firms with 20 employees or less. Employment termination under the $C N E$ is not subject to costly legal and administrative procedures, severance pay is based on job duration, and no hiring restrictions are imposed. The $C N E$ has been well received since its inception. Through June 2006, job intentions using the $C N E$ accounted to close to 10 percent of total employment intentions by small firms. However, reflecting strong substitution effects, the overall impact of the $C N E$ on net job creation has been rather modest, reaching close to 40,000 in its first six months and estimated to rise to 70,000 over the medium term. ${ }^{1}$

- $\quad$ Other measures accompanying the introduction of the CNE: The reduction of social contributions for small firms increasing employment, a tax credit for the young employed in sectors with recruitment difficulties, and the scaling-up of government-aided programs seek to increase labor demand.

\footnotetext{
${ }^{1}$ Cahuc, P., and S. Carcillo, 2006, “Que peut-on attendre des Contrats Nouvelle Embauche et Première Embauche," Working Paper.
} 


\section{Box 6. France: Recent Labor Market Reforms (concluded)}

- $\quad$ The overhaul of the earned-income tax credit (PPE) in September 2005: Tax credits were sharply raised, and the lag in the tax credit disbursements was significantly shortened, thus improving work incentives.

- $\quad$ Recent proposals to lift the employment rate of older workers: Proposed measures that seek to eliminate the tax for firing workers aged 50 or older (contribution Delalande) raise the margins for accumulating pension credits, increase the pension rate (surcôte) for those who continue to work, and improve the terms for gradual retirement should boost incentives for older workers to remain in the labor force. A new temporary employment contract for workers aged 55 or older could, in principle, facilitate their employment but is likely to have a modest impact given its limited scope.

Many of these reforms have continued to add to the already large budgetary costs of labor market policies in France. In 2006, public resources spent on labor market policies will reach 2.4 percent of GDP (Table). About half of this amount is devoted to across-theboard exemptions of employers' social security contributions (SSC), which grew considerably following the sharp upward adjustment of the minimum wage (SMIC) during the 2003-05 period. These exemptions presently apply to all workers with wages between 1 and 1.6 times the SMIC as well as specific sectors, such as the catering sector and services to households. About 0.7 percent of GDP is spent on subsidized jobs, aids to enterprise creation, and promotion of life-long and vocational training. The earned-income tax credit (PPE) will amount to 0.2 percent of GDP, while other tax expenditures (after excluding the SSC cuts) could reach 0.2 percent. For households, budgetary support would range from the personal income tax (PIT) credit for hiring an employee for personal services to partial PIT exemption for apprentices. Firms would also benefit from the corporate income tax credits for life-long training, management of apprentices, or activities in special urban areas.

\section{Overview of the Budgetary Cost of Labor Market Policies, 2006}

(In percent of GDP)

\begin{tabular}{ll}
\hline Social security contribution exemptions & 1.27 \\
Across the board exemptions for low wages & 1.22 \\
Specific exemptions (services, catering sector) & 0.05 \\
Subsidized jobs and aids to enterprise creation & 0.41 \\
Promotion of life-long and vocational training & 0.25 \\
Earned-income tax credit (PPE) & 0.18 \\
PIT credit to promote labor supply & 0.14 \\
CIT credit to promote labor demand & 0.04 \\
Reduced VAT in cafeterias on work premises & 0.05 \\
Total & 2.39 \\
\hline
\end{tabular}

Source: 2006 Central Government and Social Security Budget Laws. 
36. The authorities acknowledged that the state's presence in commercial activities was still too pervasive, noting that it was steadily diminishing. The state had been withdrawing from participation in commercial activities, most prominently in the privatization of highways, the partial flotation of the electricity and gas utilities, and the impending divestiture of the Paris airports operator. The authorities observed that the planned merger of the gas utility with a domestic firm, which many perceived as an attempt to prevent takeover by a foreign firm, was a mere acceleration of existing business plans, which would reduce the state's stake in the utility. The staff noted the ambiguity of policies in this area pointing to a new law, covering 11 so-called sensitive sectors, specifically adopted to limit the possibility of hostile takeovers.

37. Efforts to boost $R \& D$ spending are being reinvigorated. Mindful of the importance of research and development for growth and participation in globalization, the authorities have started to provide R\&D and infrastructure support to selected research clusters and have created a new agency for innovation. While supporting the objectives of this policy, the staff agreed with the OECD position calling for limiting bureaucracy and budgetary costs. Moreover, as it is mostly the private sector that lags in terms of R\&D spending by international comparison, it will be important to focus on public-private partnerships and increased incentives for individual researchers.

\section{Staff ApPraisal}

38. The economic outlook is broadly positive thanks in part to policies of consolidation and reform, but significant structural weaknesses persist, requiring further growth-enhancing reforms. Greater flexibility in labor and product markets have increased economic efficiency, while pension and health care reforms - alongside ongoing fiscal consolidation - have brightened prospects for fiscal sustainability. Even so, France's relative position in the global economy has deteriorated appreciably, the level of projected age-related spending remains comparatively high, as do taxes, unemployment benefits, and minimum wages - compressing employment rates. Further reforms are needed to durably reduce unemployment, prepare for an aging population, and allow the economy to fully benefit from globalization. Reforms have been adopted successfully when they were well explained to the public and consensus was built among stakeholders. Thus, the authorities' emphasis on raising public awareness of the need and benefits of structural reforms, including via councils of main stakeholders, is highly welcome.

\section{These reforms will need to cover several areas to exploit synergies and balance}

the interests of various stakeholders. There are three main priorities: First, fiscal adjustment through expenditure reduction should remain high on the agenda. Second, two labor market reforms are key, namely, a marked reduction in the judicial uncertainty surrounding permanent labor contracts, and a widening of the differentials among the median wage, the minimum wage, and out-of-work benefits. Third, in product markets, deregulation of the services sector and full disengagement of the state from commercial activities are 
crucial. In line with the authorities' welcome emphasis on raising public awareness of the needs and benefits of structural reforms, the electoral calendar provides an opportunity to place these economic priorities at the centre of an informed public debate. Implementation should start immediately following the 2007 elections.

40. Economic prospects are favorable. In the near term, growth is expected to continue in the range between 2 and $2 \frac{1}{2}$ percent per year, and unemployment is likely to decline appreciably. Risks are broadly balanced and relate mainly to external developments, given the heightened sensitivity of the economy to global developments. In this context, it is encouraging that exports have picked up following a few years of lackluster performance. Together with the fact that the exchange rate appears broadly in line with fundamentals, this has alleviated concerns about competitiveness, but the slow response to the global expansion still points to the presence of supply rigidities and the need for flexibility-enhancing structural reforms. Such reforms would also be consistent with addressing the risk of a disorderly unwinding of global imbalances. For the medium term, prospects are for potential growth to remain higher than previously expected because of improved demographics and the effects of structural reforms.

\section{Fiscal consolidation needs to build on the significant progress achieved during}

the past three years. Underlying adjustment has been noteworthy, averaging slightly more than $1 / 2$ of 1 percentage point of GDP per year and permitting the general government deficit to settle below 3 percent of GDP. Maintaining central government spending constant in real terms for four consecutive years and bringing health care spending on track after years of overruns have enhanced the credibility of fiscal policy. Still, recent consolidation has relied mainly on increases in revenues. Against this background, the aim to balance the budget by 2010 is appropriate, as is the focus on expenditure restraint. Nonetheless, stronger adjustment in 2007 would be desirable to attain a more evenly-paced consolidation path. Moreover, it will be essential to quickly make the specific policy choices necessary to keep spending within the proposed norms, especially for social security and local governments. A further strengthening of the capacity of national fiscal institutions to contribute to the public debate on fiscal policy will be helpful.

\section{Tax reforms have improved the economy's growth potential, but further reductions in the tax burden are desirable and should be funded by additional} expenditure cuts. The focus of tax reform on making work pay and fostering investment is highly welcome. However, the increasing recourse to tax expenditure needs to be stemmed to prevent the erosion of the benefits of improved spending discipline. While the concern to fund social security not just from taxes on labor is legitimate, the current proposals to shift taxation to other tax bases will have negligible economic effects.

43. The financial sector's profitability and capitalization put it in a good position to manage increasing risks, to which supervisors should remain highly attentive. These risks pertain to the likely transitory character of current low provisioning, the possible 
relaxation of loan standards in the face of sharp competition for market share, rising exposure abroad, and the search for profits in less liquid market segments. Encouragingly, stress tests conducted by banks and supervisors indicate considerable resilience to large shocks.

\section{By improving its efficiency further, the financial sector could contribute} appreciably to lifting the economy's growth potential. Phasing out administrative savings schemes should increase competition for resources, foster financial innovation, and help the development of risk capital markets. The current initiative to reform the mortgage market should be expanded to permit more flexible use of prudently-valued housing collateral. The postal bank should be allowed to develop into a full-fledged bank and be privatized. Complete integration of Europe's financial markets will be a boon for growth. To expedite this process, France and other member countries should swiftly harmonize financial products, regulation, and legislation and integrate financial market infrastructure.

\section{Structural reforms in labor and product markets remain essential to boost long-} term growth and secure fiscal sustainability. Following recent reforms, the labor market has become more flexible, raising supply, but the high level of the minimum wage and its ongoing significant increases continue to curb labor demand, lead to excessive wage compression, and require budgetary resources to keep labor costs manageable. Future labor market reforms need to break this vicious circle by focusing on reforms that do not burden the budget. Priority should be given to drastically reducing the legal uncertainty surrounding permanent labor contracts and increasing the wedge between the minimum wage and the median wage and between out-of-work benefits and the minimum wage. This would allow people who progress in their career to see the benefit of their efforts and reward the return to work. Simultaneously strengthening product and services market reform would lend support for labor market reforms as it is likely to increase purchasing power. Deregulating the services sector, reducing the administrative burden on enterprises, and accelerating the withdrawal of the state from commercial activities will appreciably boost output and consumer welfare. Regarding international trade, France should contribute actively within the EU to help revive multilateral trade negotiations.

46. It is proposed that the next Article IV Consultation take place on the standard 12month cycle. 
Figure 1. France: Economic Developments 1/ (Percent change)
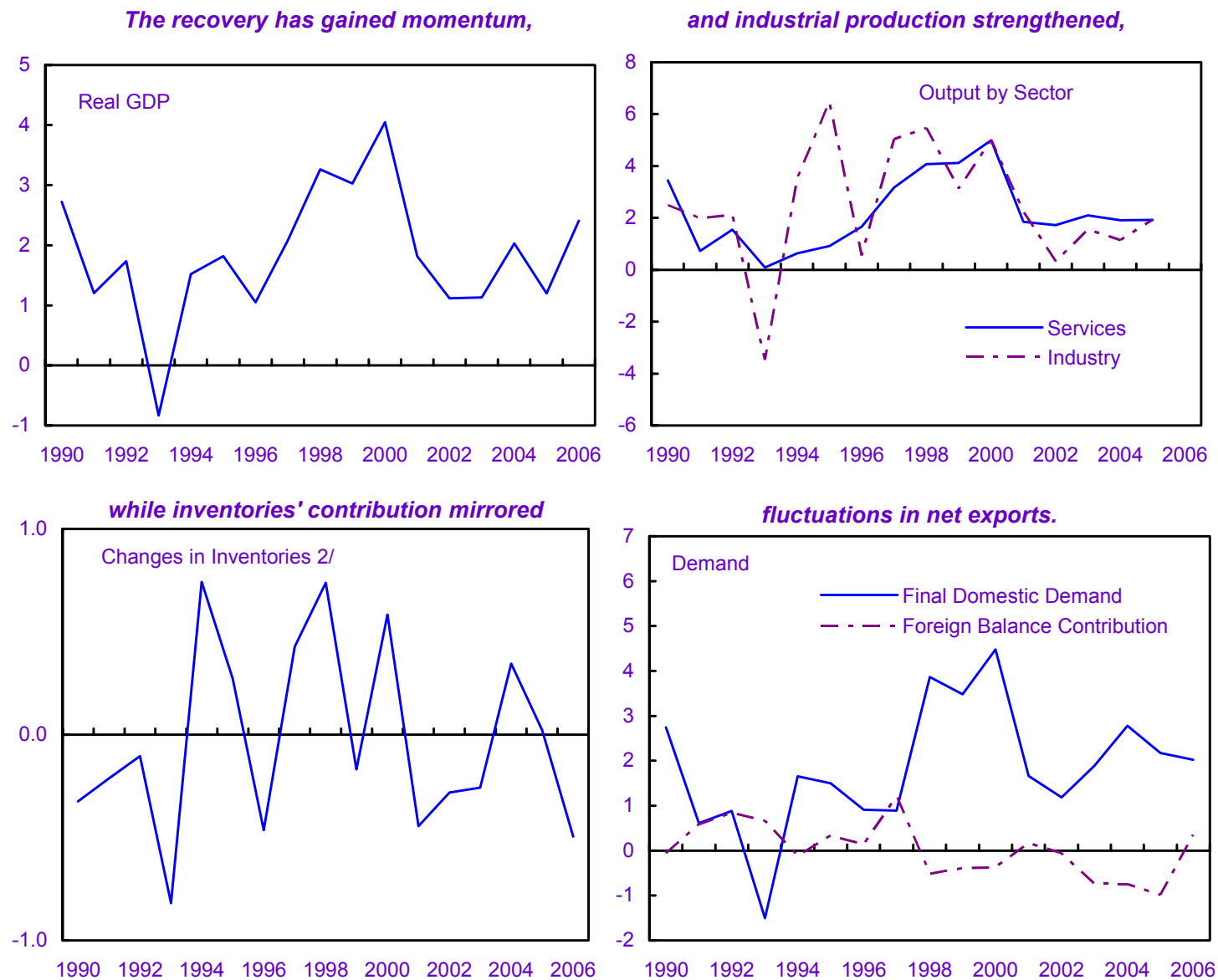

Private consumption remained steady,
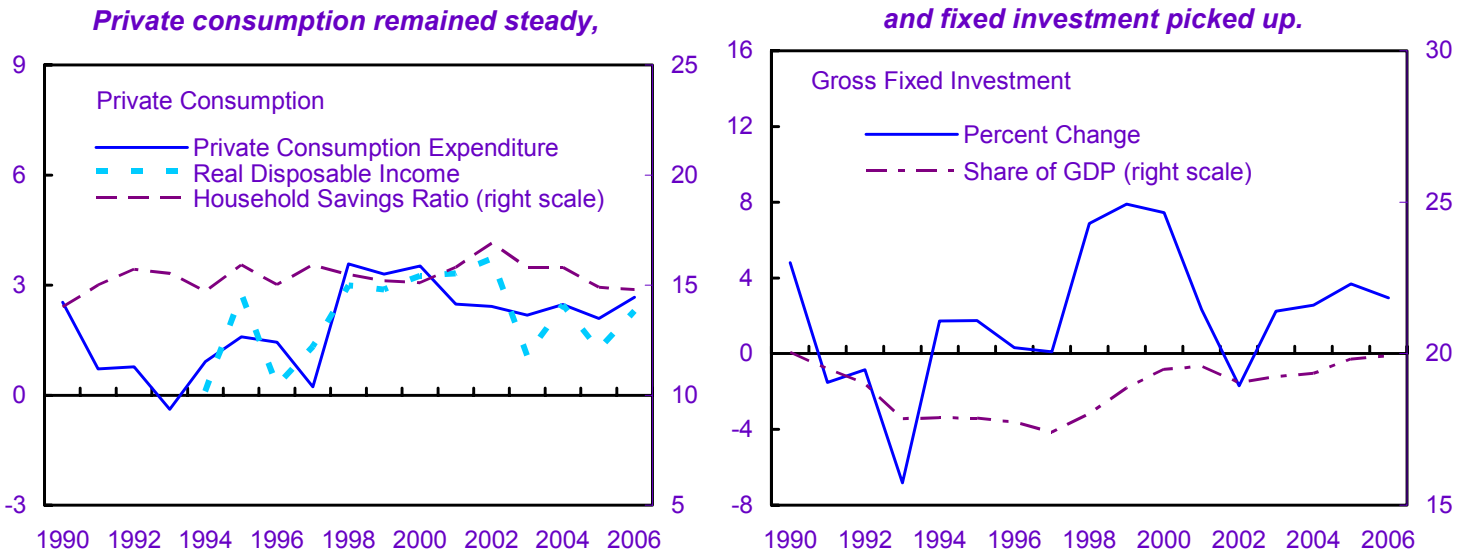

Sources: INSEE, National Accounts; WEFA; and IMF, WEO.

1/ 2006 data are projections.

2/ Contribution to growth of GDP. 
Figure 2. France: Consumption Determinants

(Percent change)
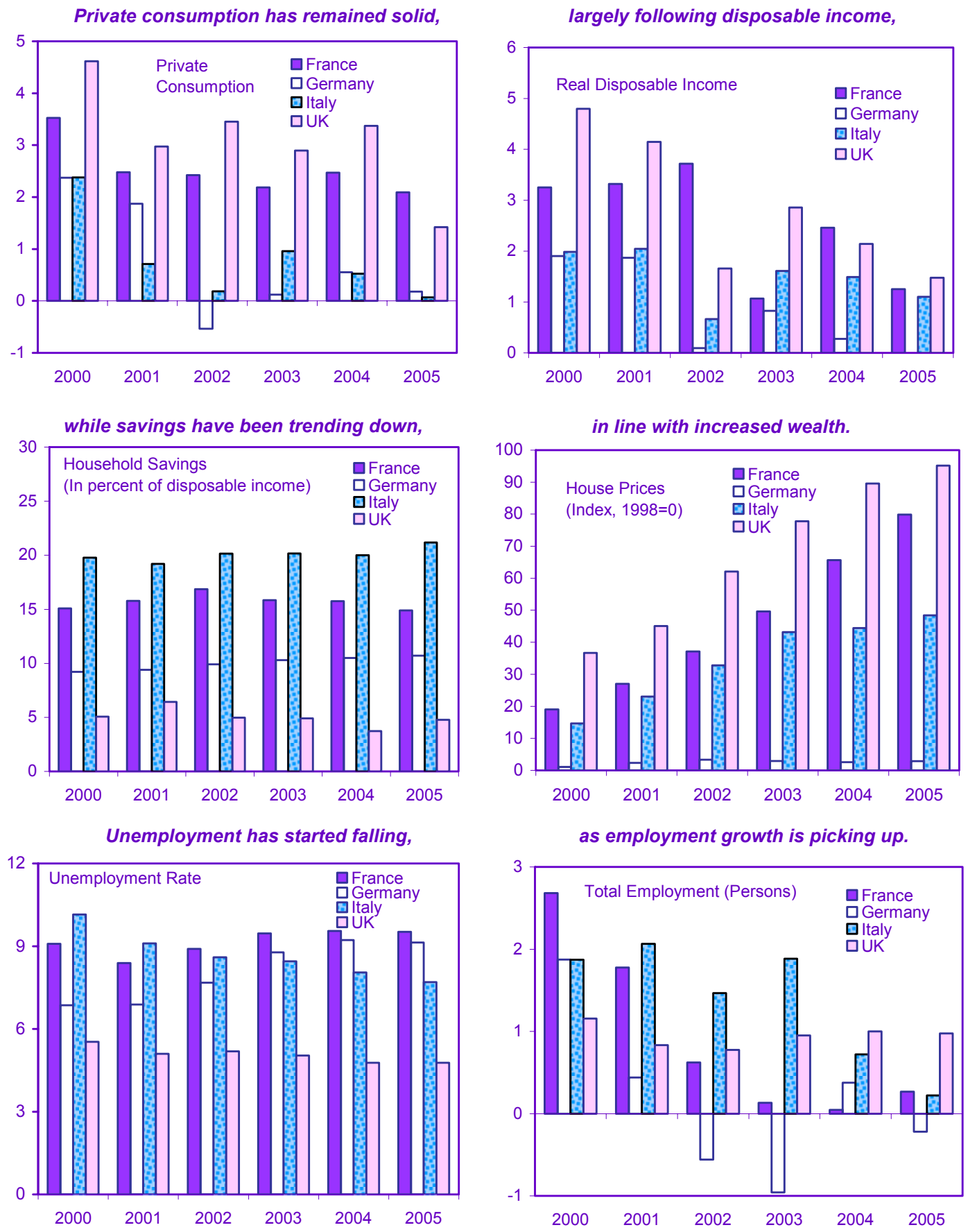

Sources: IMF, WEO; AMECO; Cronos database; Datastream; national authorities; and IMF staff estimates. 
Figure 3. France: Determinants of Investment

(Percent change)
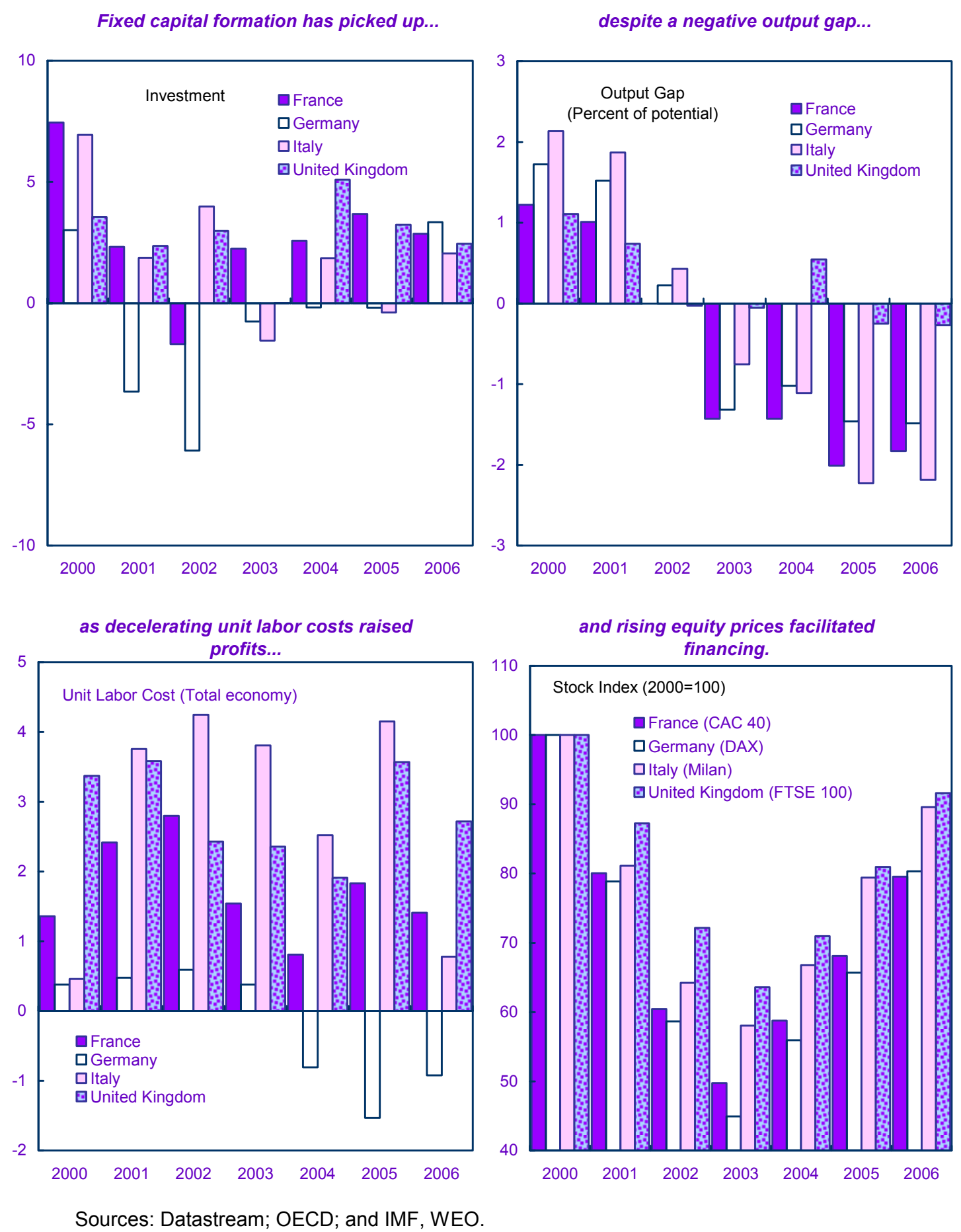
Figure 4. France: Labor and Product Market Indicators
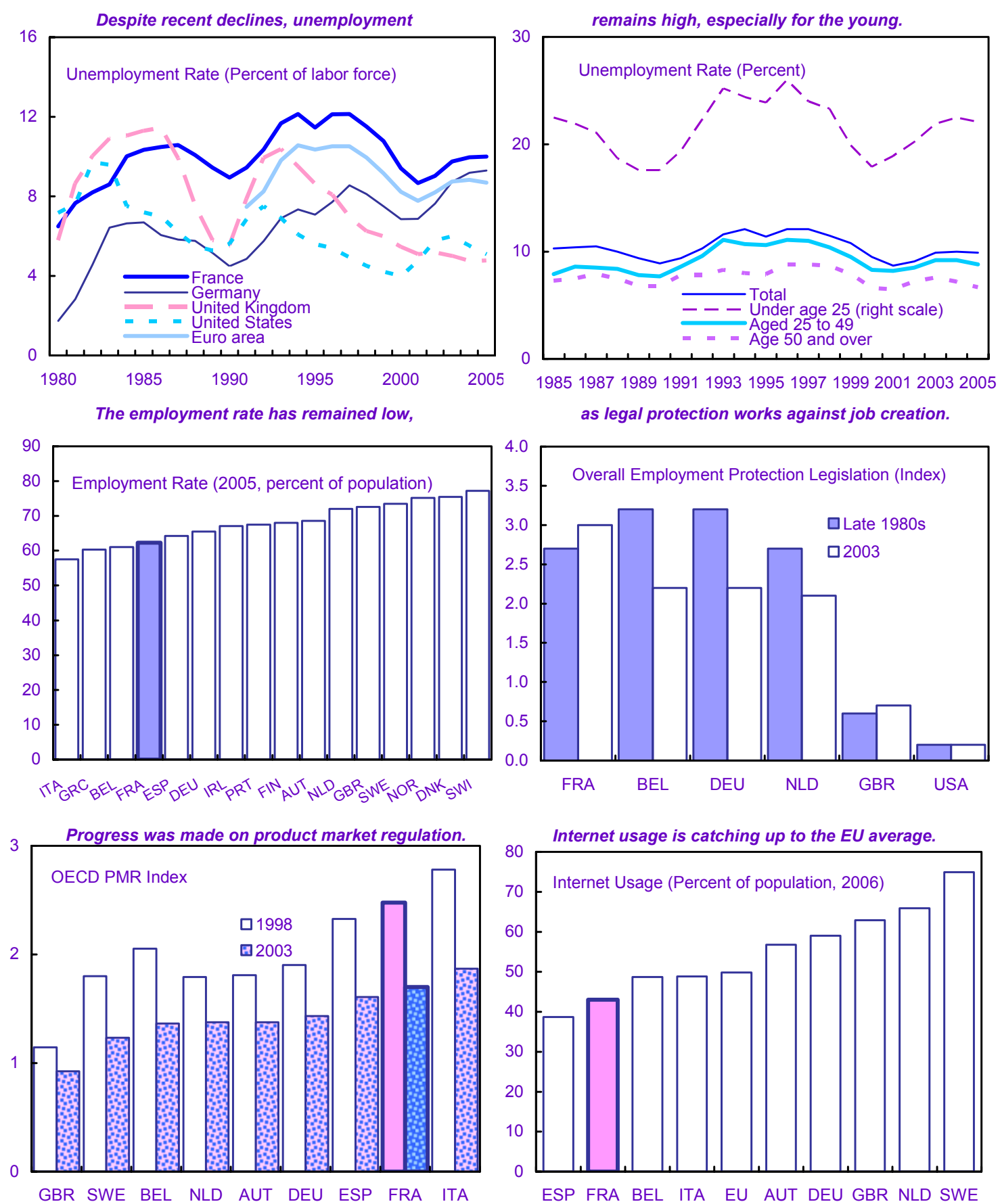

Sources: OECD; Datastream; Nielsen; and IMF staff calculations. 
Figure 5. France: Inflation Analysis 1/

(Percent change over same period of previous year)
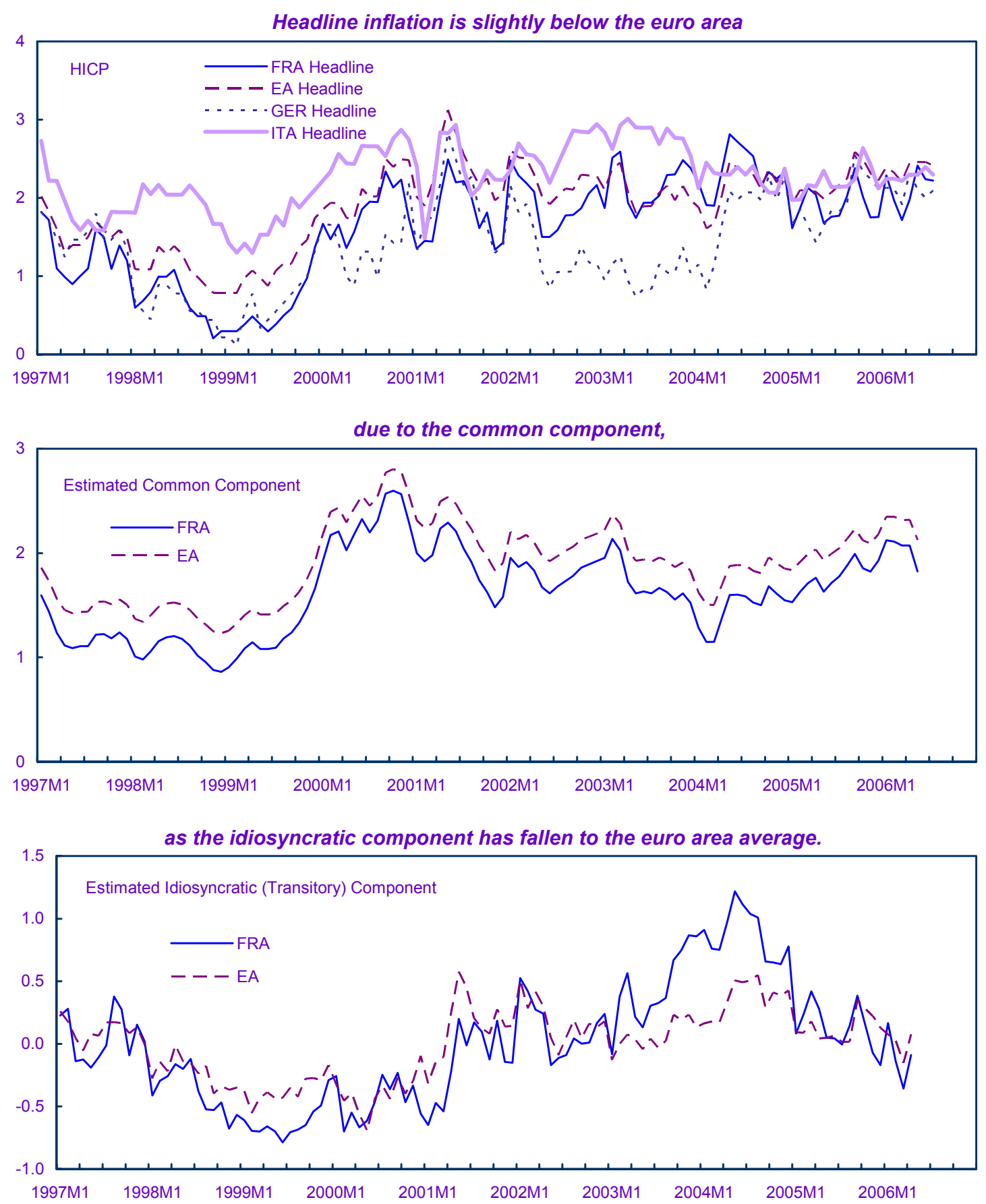

Sources: Cronos database; and IMF staff calculations.

1/ Permanent (common) and transitory (idiosyncratic) components extracted with a Generalized Dynamic Factor Model applied to 4-digit categories of the HICP. 
Figure 6. France: Policy Conditions

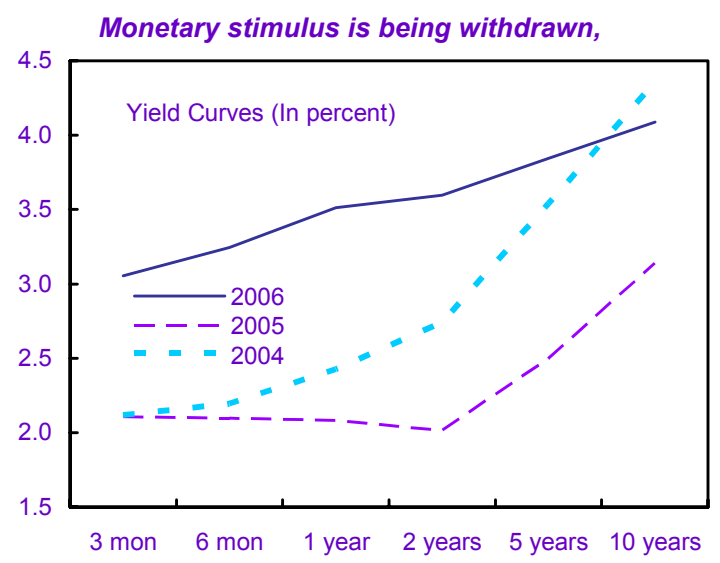

resulting in rising short-term real interest rates,

while the real effective exchange rate stabilized,
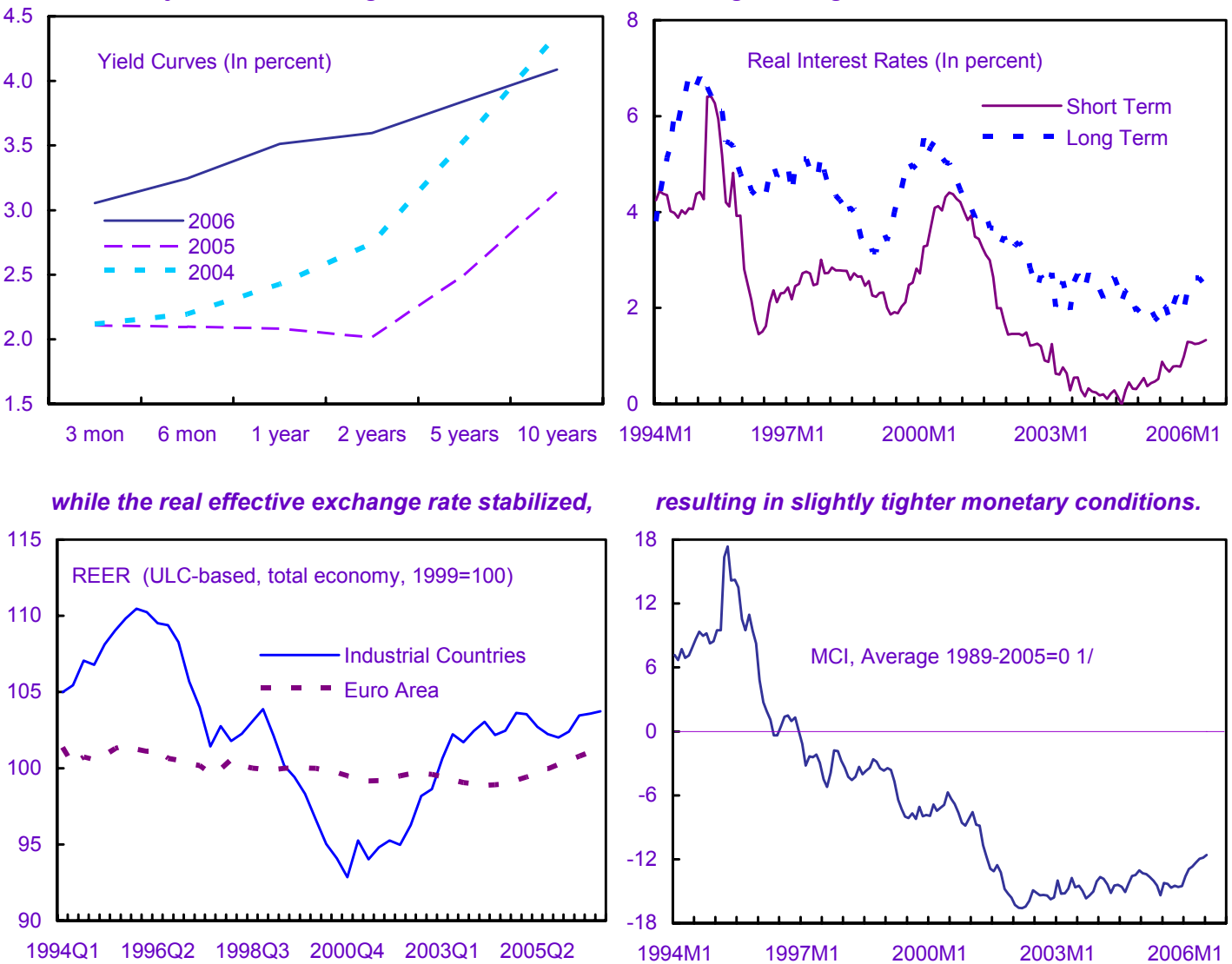

resulting in slightly tighter monetary conditions.
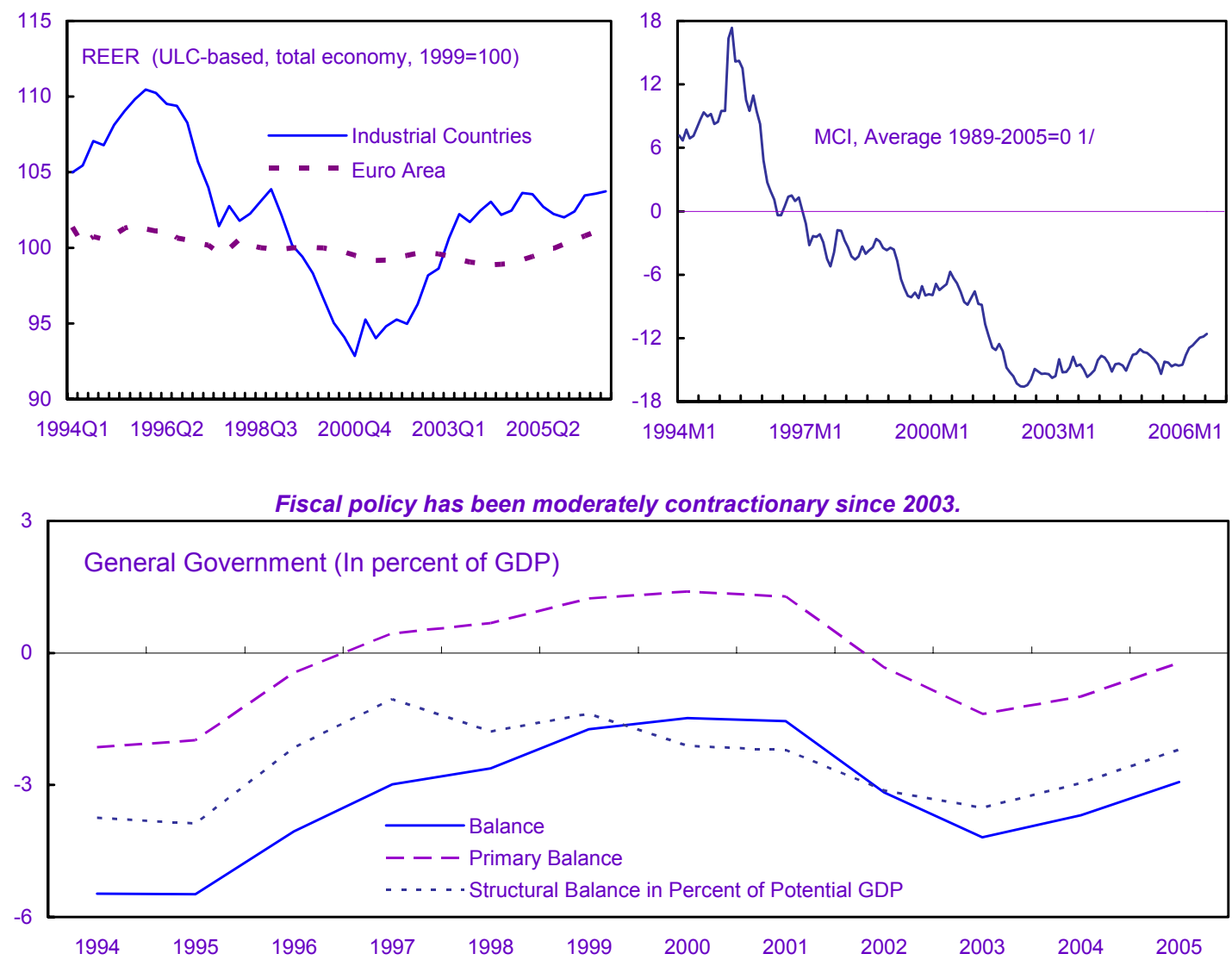

Sources: Datastream-Thomson Financial; Cronos database; and IMF, IFS and WEO.

$1 /$ The monetary conditions index is a weighted average of the real effective exchange rate and the short-term real interest rate, with weights, 1 and 2.5, respectively. A higher index implies tighter conditions (using underlying $\mathrm{CPI}$ ). 
Figure 7. France: Housing Market
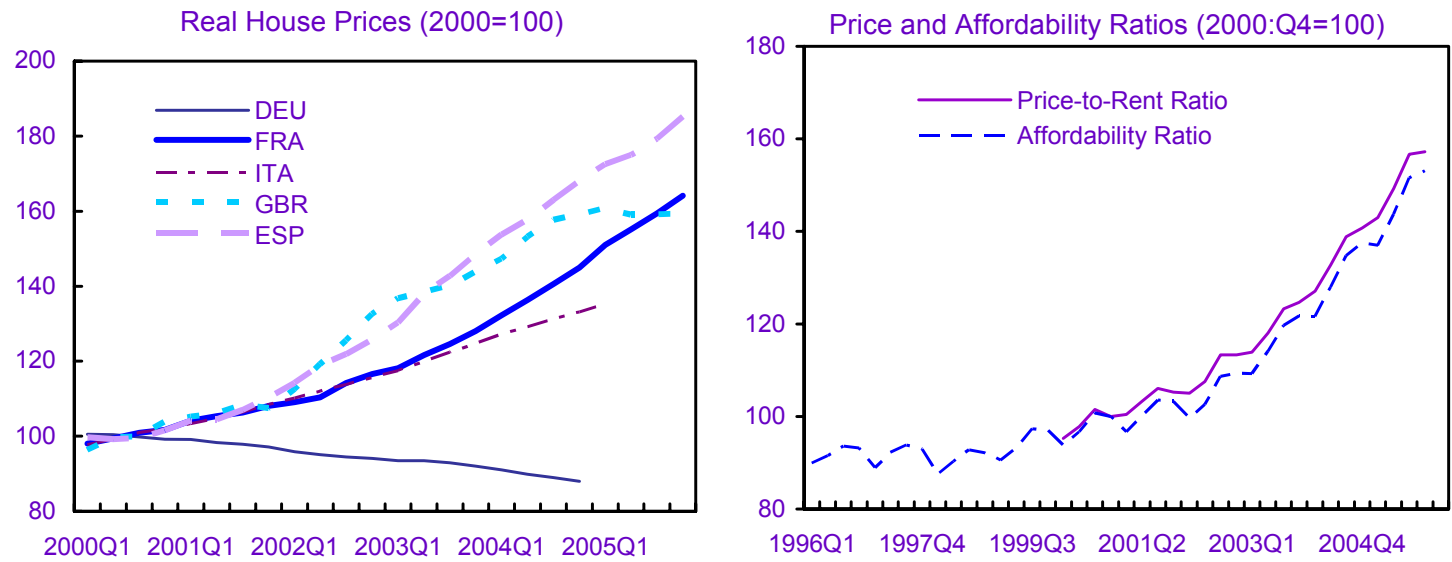

Lending to Households

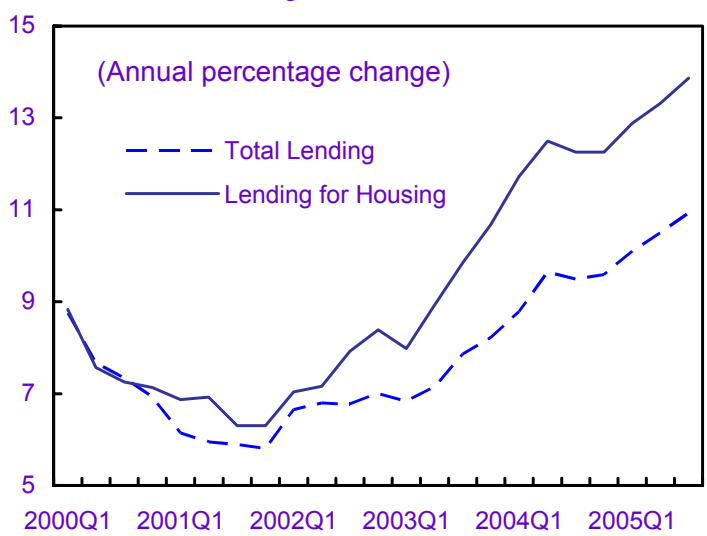

Outstanding Lending to Households

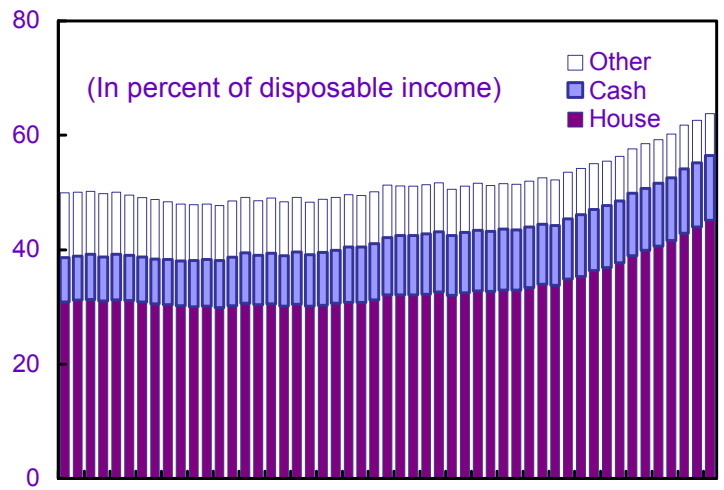

1993Q2 1995Q2 1997Q2 1999Q2 2001Q2 2003Q2 2005Q2
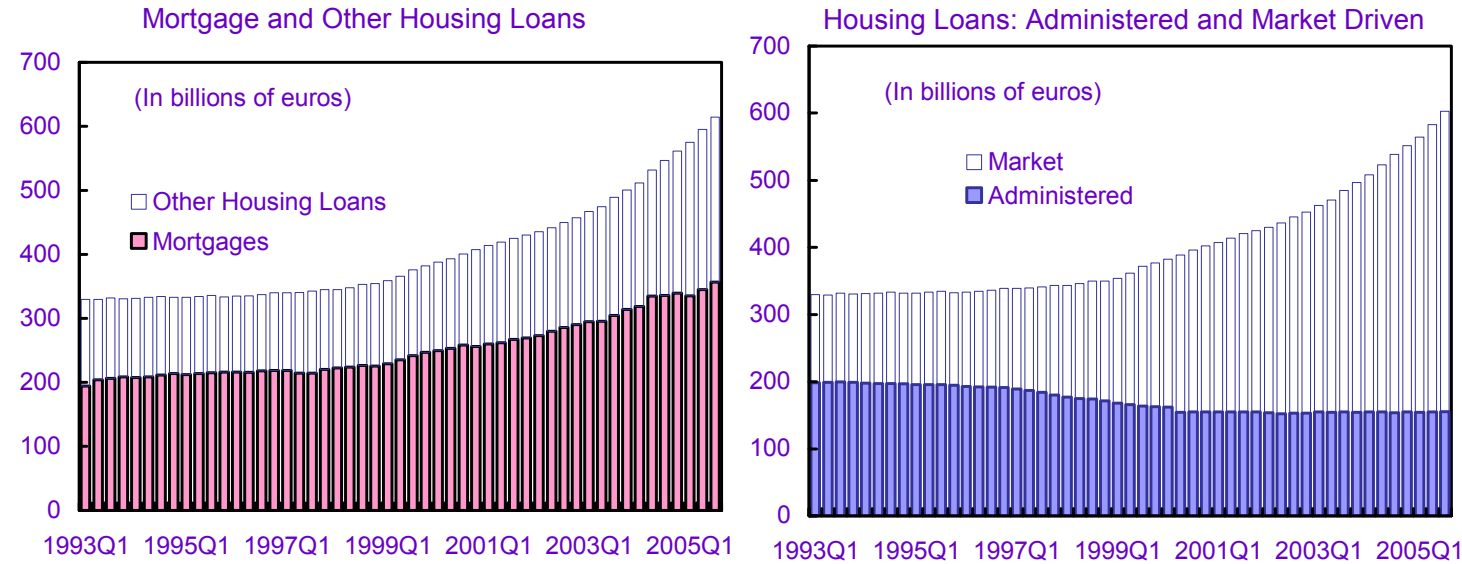

1993Q1 1995Q1 1997Q1 1999Q1 2001Q1 2003Q1 2005Q1

1993Q1 1995Q1 1997Q1 1999Q1 2001Q1 2003Q1 2005Q1

Sources: Banque de France; and BIS-National Sources. 
Figure 8. France: Financial Sector Indicators
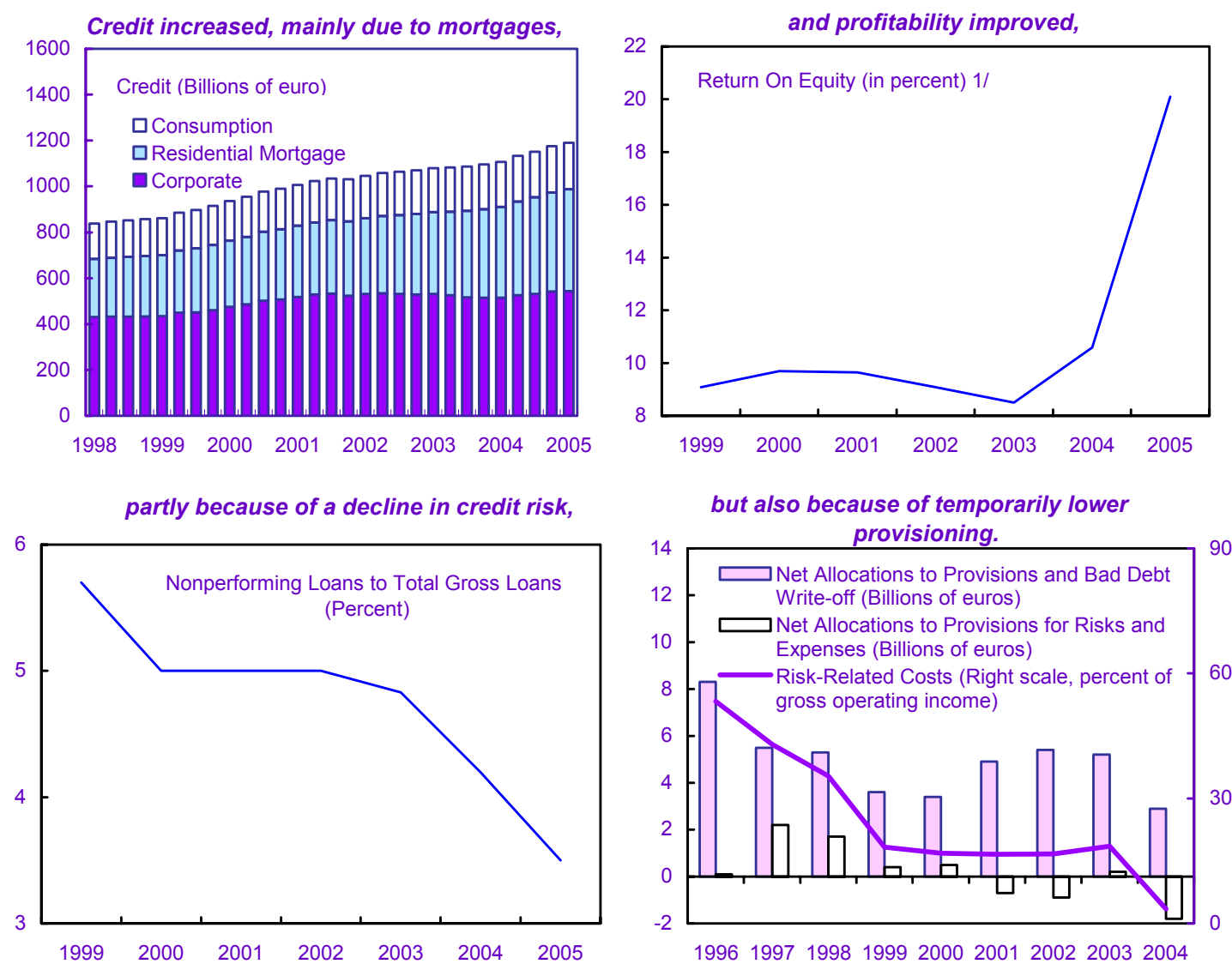

Risk premium has increased, 2/
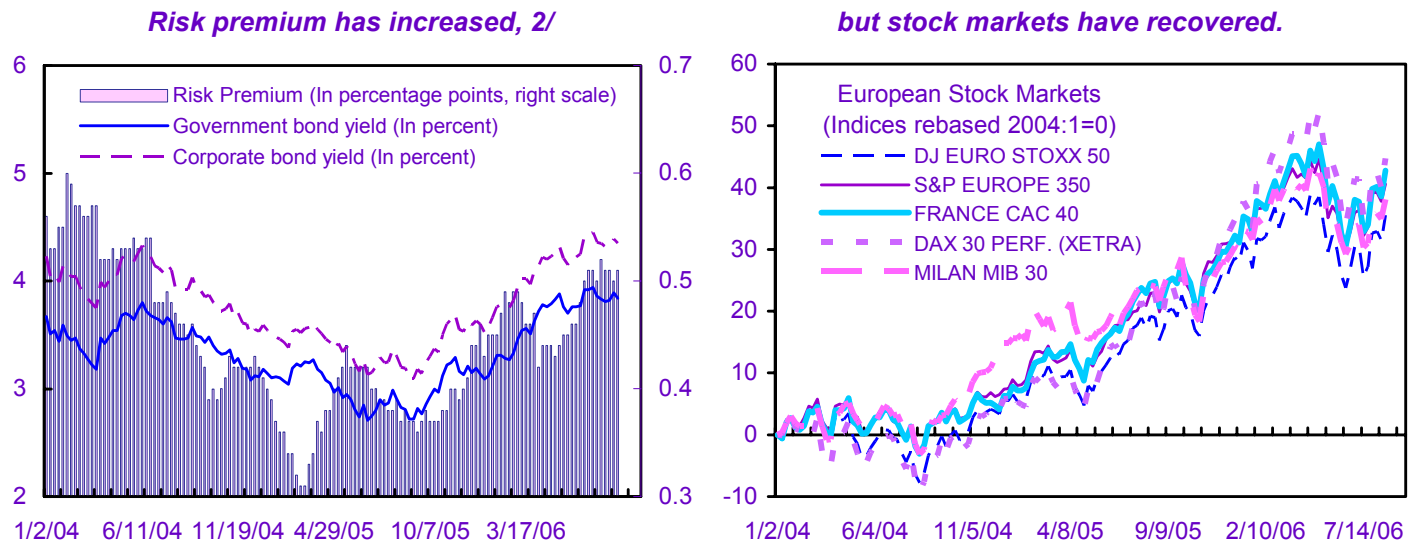

Sources: Banque de France; and Datastream/Thompson Financial.

1/ All credit institutions aggregated data on a parent-company basis.

2/ Lehman Brothers Euro-aggregate government, corporate issues redemption yields. 
Table 1. France: Main Economic Indicators, 2002-11

(Annual percentage change; unless otherwise indicated)

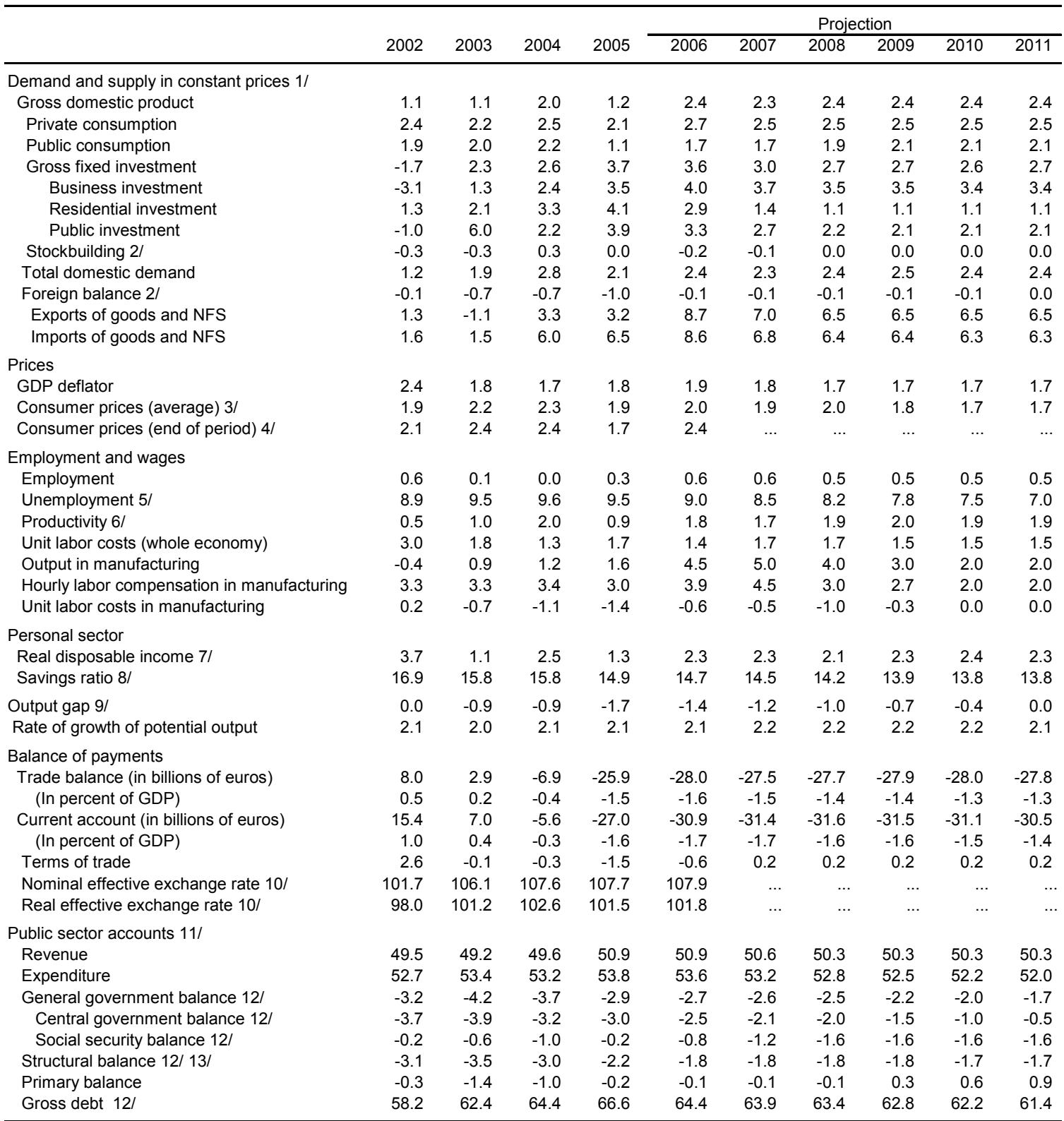

Sources: Banque de France; data provided by the authorities; and IMF staff estimates.

$1 /$ Data from the INSEE quarterly national accounts system.

2/ Change as percentage of previous year's GDP.

3/ Harmonized CPI.

4/ For 2006, year-on-year April.

$5 /$ In percent of labor force; harmonized index.

6/ GDP over total employment.

7/ Personal disposable income deflated by the implicit deflator for private consumption.

8/ In percent of household disposable income.

9/ In percent of potential GDP.

$10 /$ Index; base $2000=100$. For 2006, data available up to April.

11/In percent of GDP; data for 2001-02 exclude the proceeds from the sale of UMTS licenses, which amount to about 0.1 percent of GDP.

12/ Maastricht definition.

13/ Data for 2005 exclude the EDF pension fund transfer ( 0.5 percent of GDP); in percent of potential GDP. 
Table 2. France: Vulnerability Indicators, 2001-06

(In percent of GDP; unless otherwise indicated)

\begin{tabular}{|c|c|c|c|c|c|c|c|}
\hline & \multirow[b]{2}{*}{2001} & \multirow[b]{2}{*}{2002} & \multirow[b]{2}{*}{2003} & \multirow[b]{2}{*}{2004} & \multirow[b]{2}{*}{2005} & Estimate & \multirow{2}{*}{ Date } \\
\hline & & & & & & 200 & \\
\hline \multicolumn{8}{|l|}{ External indicators } \\
\hline Exports (annual percentage change, in U.S. dollars) & -0.4 & 2.5 & 19.7 & 16.5 & 5.6 & $\ldots$ & $\ldots$ \\
\hline Imports (annual percentage change, in U.S. dollars) & -1.3 & 4.2 & 21.7 & 19.7 & 10.6 & $\ldots$ & $\ldots$ \\
\hline Terms of trade (annual percentage change) & 0.7 & 2.6 & -0.1 & -0.3 & -1.5 & $\ldots$ & $\ldots$ \\
\hline Current account balance & 1.6 & 1.0 & 0.4 & -0.3 & -1.6 & $\ldots$ & $\ldots$ \\
\hline \multicolumn{8}{|l|}{ Of which } \\
\hline Inward portfolio investment (debt securities, etc.) & 8.0 & 5.3 & 11.1 & 8.0 & 10.6 & $\ldots$ & $\ldots$ \\
\hline Inward foreign direct investment & 3.8 & 3.4 & 2.4 & 1.5 & 3.0 & $\ldots$ & $\ldots$ \\
\hline Other investment liabilities (net) & 2.9 & 1.9 & 1.4 & 3.8 & 1.2 & $\ldots$ & $\ldots$ \\
\hline \multicolumn{8}{|l|}{ Total reserves minus gold } \\
\hline (In billions of U.S. dollars, end-of-period) & 31.7 & 28.4 & 30.2 & 35.3 & 27.8 & 32.4 & June \\
\hline Euros per U.S. dollar (period average) & 1.118 & 1.063 & 0.886 & 0.805 & 0.804 & 0.832 & June \\
\hline \multicolumn{8}{|l|}{ Market indicators } \\
\hline \multicolumn{8}{|l|}{ Financial markets } \\
\hline Public sector debt (Maastricht definition) & 56.3 & 58.2 & 62.4 & 64.4 & 66.6 & $\ldots$ & $\ldots$ \\
\hline 3-month T-bill yield (percentage points, end-of-period) & 3.3 & 2.9 & 2.2 & 2.2 & 2.5 & 3.0 & June \\
\hline 3-month T-bill yield in real terms (percentage points, end-of-period) & 1.9 & 0.9 & -0.3 & -0.2 & 0.8 & 0.7 & June \\
\hline U.S. 3-month T-bill & 1.7 & 1.2 & 0.9 & 2.2 & 3.9 & 4.8 & June \\
\hline Spread with the U.S. T-bill (percentage points, end-of-period) & 1.6 & 1.7 & 1.3 & 0.0 & -1.4 & -1.8 & June \\
\hline 5- to 8-year government bond (percentage points, end-of-period) & 5.1 & 4.4 & 4.4 & 3.7 & 3.4 & 4.1 & June \\
\hline 10-year government bond (United States) & 5.1 & 4.0 & 4.3 & 4.2 & 4.5 & 4.7 & March \\
\hline Spread with U.S. bond (percentage points, end-of-period) & 0.0 & 0.4 & 0.1 & -0.5 & -1.0 & -0.7 & June \\
\hline Yield curve (10 year - 3 month, percentage points, end-of-period) & 1.7 & 1.5 & 2.2 & 1.5 & 1.0 & 1.1 & June \\
\hline Stock market index (period average) & 80.9 & 63.3 & 52.9 & 63.3 & 74.4 & 88.2 & July \\
\hline Real estate prices (index, $2000=100$, period average) & 106.1 & 118.7 & 135.7 & 156.7 & 172.8 & 188.1 & 006:Q2 \\
\hline \multicolumn{8}{|l|}{ Credit markets (end-of-period 12-month growth rates) } \\
\hline Credit to the private sector & 6.1 & 4.0 & 5.2 & 8.3 & 8.9 & 11.5 & May \\
\hline Bank credit to households & 6.1 & 7.1 & 7.8 & 9.6 & 11.7 & 11.9 & May \\
\hline Housing loans & 6.3 & 8.0 & 9.9 & 13.6 & 15.0 & 15.1 & May \\
\hline Bank credit to nonfinancial enterprises & 3.3 & 2.8 & -1.1 & 6.0 & 7.2 & 10.7 & May \\
\hline \multicolumn{8}{|l|}{$\begin{array}{l}\text { Sectoral risk indicators } \\
\text { Household sector }\end{array}$} \\
\hline Household savings ratio & 15.8 & 16.9 & 15.8 & 15.8 & 14.9 & $\ldots$ & $\ldots$ \\
\hline Household financial savings ratio & 6.9 & 8.0 & 6.7 & 5.9 & 4.8 & $\ldots$ & $\ldots$ \\
\hline Real estate household solvency ratio (index, 2000=100) $1 /$ & 99.1 & 101.9 & 97.9 & 89.4 & 91.0 & 90.8 & 006:Q2 \\
\hline \multicolumn{8}{|l|}{ Corporate sector } \\
\hline Profitability of business sector (financial margin) & 38.5 & 37.8 & 37.9 & 37.6 & 37.0 & $\ldots$ & $\ldots$ \\
\hline Investment ratio & 18.3 & 17.3 & 17.0 & 17.4 & 17.6 & $\ldots$ & $\ldots$ \\
\hline Savings ratio & 16.5 & 15.1 & 15.8 & 14.4 & 13.4 & $\ldots$ & $\ldots$ \\
\hline Self-financing ratio & 83.3 & 80.7 & 87.0 & 77.2 & 70.1 & $\ldots$ & $\ldots$ \\
\hline \multicolumn{8}{|l|}{ Banking sector } \\
\hline Share of housing loans in bank credit to the private sector & 29.4 & 31.0 & 32.8 & 34.7 & 36.6 & 36.3 & May \\
\hline Share of nonperforming loans in total loans & 5.0 & 5.0 & 4.8 & 4.2 & 3.5 & $\ldots$ & $\ldots$ \\
\hline Ratio of nonperforming loans net of provisions to capital & 12.6 & 12.6 & 11.6 & 9.8 & 8.7 & $\ldots$ & $\ldots$ \\
\hline Liquid assets to total short-term liabilities & 152.5 & 157.0 & 153.7 & 155.1 & 148.1 & $\ldots$ & $\ldots$ \\
\hline Return on assets $2 /$ & 0.5 & 0.5 & 0.4 & 0.5 & 0.6 & $\ldots$ & $\ldots$ \\
\hline Return on equity $2 /$ & 9.6 & 9.1 & 8.5 & 10.6 & 11.9 & $\ldots$ & $\ldots$ \\
\hline Regulatory capital to risk-weighted assets & 12.1 & 11.5 & 11.9 & 11.5 & 11.4 & $\ldots$ & $\ldots$ \\
\hline
\end{tabular}

Sources: Banque de France; IMF, International Financial Statistics; Bloomberg; FNAIM; and Commission Bancaire.

$1 /$ This index combines the effect of real disposable income, repayment conditions for loans, real estate prices, and interest subsidies.

2/ All credit institutions aggregated data on a parent-company basis. 
Table 3. France: General Government Accounts, 2000-05 1/

\begin{tabular}{|c|c|c|c|c|c|c|}
\hline & 2000 & 2001 & 2002 & 2003 & 2004 & 2005 \\
\hline \multicolumn{7}{|l|}{ General government } \\
\hline Revenue & 50.2 & 50.0 & 49.5 & 49.2 & 49.6 & 50.9 \\
\hline Tax revenue & 44.1 & 43.8 & 43.1 & 42.8 & 43.1 & 44.0 \\
\hline \multicolumn{7}{|l|}{ Of which } \\
\hline VAT & 7.4 & 7.2 & 7.1 & 7.0 & 7.2 & 7.4 \\
\hline Income tax & 3.5 & 3.3 & 3.0 & 3.0 & 2.8 & 2.9 \\
\hline Corporate tax & 2.7 & 3.0 & 2.6 & 2.4 & 2.5 & 2.4 \\
\hline TIPP & 1.7 & 1.6 & 1.6 & 1.5 & 1.5 & 1.4 \\
\hline Nontax revenue & 6.0 & 6.2 & 6.4 & 6.3 & 6.4 & 6.9 \\
\hline Expenditures & 51.6 & 51.7 & 52.7 & 53.4 & 53.2 & 53.8 \\
\hline \multicolumn{7}{|l|}{ Of which } \\
\hline Salaries & 13.3 & 13.3 & 13.5 & 13.6 & 13.5 & $\ldots$ \\
\hline Pensions & 12.3 & 12.1 & 12.3 & 12.5 & 12.6 & $\ldots$ \\
\hline Health expenditure & 6.4 & 6.7 & 6.9 & 7.3 & 7.3 & $\ldots$ \\
\hline Other social transfers & 5.5 & 5.5 & 5.7 & 5.7 & 5.6 & $\ldots$ \\
\hline Balance 2/ & -1.5 & -1.6 & -3.2 & -4.2 & -3.7 & -2.9 \\
\hline Primary balance & 1.4 & 1.3 & -0.3 & -1.4 & -1.0 & -0.2 \\
\hline Structural balance $3 /$ & -2.1 & -2.2 & -3.1 & -3.5 & -3.0 & -2.2 \\
\hline Central government balance $2 /$ & -2.5 & -2.5 & -3.7 & -3.9 & -3.2 & -3.0 \\
\hline Social security balance $2 /$ & 0.5 & 0.4 & -0.2 & -0.6 & -1.0 & -0.2 \\
\hline Local government balance 2 & 0.2 & 0.1 & 0.1 & 0.0 & -0.1 & -0.1 \\
\hline Other central government agencies balance $2 /$ & 0.3 & 0.3 & 0.6 & 0.3 & 0.6 & 0.4 \\
\hline Gross debt 2/ & 56.7 & 56.3 & 58.2 & 62.4 & 64.4 & 66.6 \\
\hline Interest payments & 2.9 & 3.0 & 2.9 & 2.8 & 2.7 & 2.7 \\
\hline
\end{tabular}

Sources: INSEE; and IMF staff calculations.

1/ Data for 2001-02 exclude the proceeds from the sale of UMTS licenses, which amount to about 0.1 percent of GDP. Annual national accounts.

2/ Maastricht definition.

3/ Data for 2005 exclude the EDF pension fund transfer ( 0.5 percent of GDP). 
Table 4. France: The Core Set of Financial Soundness Indicators, 2000-05

\begin{tabular}{|c|c|c|c|c|c|c|}
\hline Indicator & 2000 & 2001 & 2002 & 2003 & 2004 & 2005 \\
\hline \multicolumn{7}{|l|}{ Deposit-taking institutions $1 /$} \\
\hline Regulatory capital to risk-weighted assets & 11.9 & 12.1 & 11.5 & 11.9 & 11.5 & 11.4 \\
\hline Regulatory Tier I capital to risk-weighted assets & 9.9 & 10.5 & 9.2 & 9.0 & 8.8 & 8.2 \\
\hline Nonperforming loans net of provisions to capital & 12.8 & 12.6 & 12.6 & 11.6 & 9.8 & 8.7 \\
\hline Nonperforming loans to total gross loans & 5.0 & 5.0 & 5.0 & 4.8 & 4.2 & 3.5 \\
\hline \multicolumn{7}{|l|}{ Sectoral distribution of loans to total loans, of which } \\
\hline Deposit-takers & 31.6 & 33.6 & 33.6 & 34.2 & 34.0 & 29.8 \\
\hline Nonfinancial corporation & 20.8 & 19.5 & 19.8 & 18.9 & 18.7 & 19.1 \\
\hline Households (including individual firms) & 22.9 & 21.7 & 22.6 & 24.5 & 24.9 & 26.1 \\
\hline Nonresidents (including financial sectors) & 5.0 & 4.9 & 4.4 & 4.3 & 4.2 & 4.8 \\
\hline ROA (aggregated data on a parent-company basis) 2/ & 0.5 & 0.5 & 0.5 & 0.44 & 0.5 & 0.6 \\
\hline ROA (main groups on a consolidated basis) $3 /$ & 0.60 & 0.45 & 0.43 & 0.39 & 0.53 & 0.50 \\
\hline ROE (aggregated data on a parent-company basis) 2/ & 9.7 & 9.6 & 9.1 & 8.50 & 10.6 & 11.9 \\
\hline ROE (main groups on a consolidated basis) $3 /$ & 15.3 & 10.8 & 9.6 & 10.0 & 12.7 & 14.4 \\
\hline Interest margin to gross income & 33.3 & 32.5 & 37.5 & 35.5 & 33.2 & 32.2 \\
\hline Noninterest expenses to gross income & 67.7 & 66.9 & 65.5 & 64.4 & 63.9 & 64.4 \\
\hline Liquid assets to total assets & 19.5 & 20.4 & 20.7 & 21.6 & 21.3 & 19.9 \\
\hline Liquid assets to short-term liabilities & 138.5 & 152.5 & 157.0 & 153.7 & 155.1 & 148.1 \\
\hline \multicolumn{7}{|l|}{ Net open position in foreign exchange to capital } \\
\hline Net open positions in FX (in millions of euros) 4/ & 6,715 & 6,738 & 3,134 & 4,772 & 6,669 & 5,523 \\
\hline Net open positions in equities to Tier I capital & 3.9 & 2.9 & 4.9 & 3.5 & 4.8 & 3.9 \\
\hline
\end{tabular}

Sources: Banque de France, Commission Bancaire, BIS, and ECB.

1/ These may be grouped in different peer groups based on control, business lines, or group structure.

2/ All credit institutions' aggregated data on a parent-company basis.

$3 /$ Consolidated data for the seven main banking groups (2005, IFRS).

$4 /$ Impact of the creation of the euro has to be taken into account. 
Table 5. France: Encouraged Financial Soundness Indicators, 2000-05

\begin{tabular}{|c|c|c|c|c|c|c|}
\hline Indicator & 2000 & 2001 & 2002 & 2003 & 2004 & 2005 \\
\hline \multicolumn{7}{|l|}{ Corporate sector } \\
\hline Return on equity & 9.7 & 9.6 & 9.1 & 8.5 & 10.6 & 20.1 \\
\hline Interest paid to financial firms $1 /$ & 33.3 & 37.3 & 34.6 & 31.5 & 28.9 & 28.8 \\
\hline Number of enterprise bankruptcies (thousands) & 43.6 & 42.8 & 44.7 & 47.0 & 48.0 & 48.9 \\
\hline Number of enterprise creations (thousands) & 272.9 & 271.4 & 269.6 & 292.8 & 320.5 & 317.9 \\
\hline \multicolumn{7}{|l|}{ Deposit-taking institutions } \\
\hline Capital (net worth) to assets & 4.9 & 4.9 & 5.2 & 5.4 & 5.1 & 4.4 \\
\hline \multicolumn{7}{|l|}{$\begin{array}{l}\text { International consolidated claims of French banks, of which } \\
\text { (BIS data, as percent of total international claims) }\end{array}$} \\
\hline Advanced countries & 80.4 & 81.0 & 83.7 & 85.0 & 84.0 & 83.4 \\
\hline Developing Europe & 1.7 & 2.4 & 2.0 & 2.7 & 2.5 & 2.9 \\
\hline Latin America and Caribbean & 2.7 & 2.5 & 1.8 & 1.4 & 1.0 & 1.1 \\
\hline Africa and Middle East & 3.8 & 3.8 & 3.6 & 3.3 & 3.1 & 3.1 \\
\hline Asia and Pacific Area & 3.9 & 3.2 & 2.8 & 2.7 & 2.6 & 2.6 \\
\hline Offshore Financial Centers & 7.0 & 6.6 & 5.6 & 4.5 & 6.5 & 6.6 \\
\hline Gross asset position in financial derivatives to capital & 202 & 244 & 379 & 307 & 373 & 544 \\
\hline Gross liability position in financial derivatives to capital & 169 & 217 & 344 & 283 & 359 & 485 \\
\hline Large exposures to capital & n.a. & n.a. & 5.2 & 0.9 & 4.6 & 3.6 \\
\hline Trading income to total income & 8.0 & 6.2 & 2.4 & 16.8 & 20.0 & 23.9 \\
\hline Personnel expenses to noninterest expenses & 55.9 & 55.0 & 55.2 & 56.0 & 56.5 & 58.3 \\
\hline Customer deposits to total (noninterbank) loans & 77.3 & 81.6 & 81.5 & 82.8 & 80.6 & 78.9 \\
\hline FX loans to total loans $2 /$ & 15.1 & 15.3 & 12.6 & 11.2 & 10.8 & 12.2 \\
\hline FX liabilities to total liabilities & 17.3 & 18.4 & 15.1 & 14.2 & 15.1 & 18.2 \\
\hline \multicolumn{7}{|l|}{ Market liquidity } \\
\hline Average daily turnover ratio in the securities market & 15 & 17 & 20 & 18 & 18 & 11 \\
\hline \multicolumn{7}{|l|}{ Other financial corporations } \\
\hline Assets to total financial system assets & 17.5 & 17.9 & 17.8 & 18.3 & 18.5 & 19.0 \\
\hline Assets to GDP & 154.2 & 151.6 & 144 & 153.3 & 160.7 & 182.8 \\
\hline \multicolumn{7}{|l|}{ Households } \\
\hline Household debt to GDP & 34.9 & 35.4 & 36.4 & 37.8 & 40.0 & 42.9 \\
\hline Household debt service and principal payments to income & 2.2 & 2.6 & 2.2 & 1.9 & 1.8 & n.a. \\
\hline \multicolumn{7}{|l|}{ Real estate markets } \\
\hline Real estate prices & 8.8 & 7.9 & 8.3 & 11.7 & 15.3 & 10.3 \\
\hline $\begin{array}{l}\text { Residential real estate loans to total loans } \\
\text { Commercial real estate loans to total loans }\end{array}$ & 30.8 & 31.5 & 32.8 & 35.2 & 37.1 & 39.3 \\
\hline
\end{tabular}

Sources: Banque de France; Commission Bancaire; BIS; and ECB.

$1 /$ In percent of financial firms' gross operating surplus.

2/ Data cover interbank and customer lending to residents and nonresidents on a metropolitan basis. 
Table 6. France: Financial System Structure, 2000-05

\begin{tabular}{|c|c|c|c|c|c|c|}
\hline \multicolumn{7}{|c|}{ (End of year) } \\
\hline & 2000 & 2001 & 2002 & 2003 & 2004 & 2005 \\
\hline \multicolumn{7}{|l|}{ Number } \\
\hline \multicolumn{7}{|l|}{ Banks } \\
\hline Commercial banks & 362 & 357 & 345 & 333 & 326 & 313 \\
\hline Private & 354 & 352 & 341 & 329 & 323 & 310 \\
\hline Domestic & 140 & 144 & 142 & 138 & 139 & 131 \\
\hline Foreign & 214 & 208 & 199 & 191 & 184 & 179 \\
\hline State-owned 1/ & 8 & 5 & 4 & 4 & 3 & 3 \\
\hline Credit unions and mutuals & 154 & 148 & 136 & 129 & 127 & 125 \\
\hline \multicolumn{7}{|l|}{ Other credit institutions } \\
\hline Finance companies & 557 & 524 & 494 & 464 & 427 & 411 \\
\hline Of which: mortgage institutions & 3 & 4 & 4 & 4 & 4 & 4 \\
\hline Specialized financial institutions & 19 & 17 & 16 & 15 & 11 & 8 \\
\hline Municipal credit institutions & 22 & 21 & 21 & 21 & 21 & 21 \\
\hline Securities firms & 146 & 144 & 136 & 131 & 124 & 117 \\
\hline Insurance companies & 464 & 466 & 456 & 444 & 423 & 415 \\
\hline Life and retirement & 127 & 126 & 126 & 125 & 119 & 119 \\
\hline Nonlife & 304 & 304 & 295 & 286 & 274 & 267 \\
\hline Reinsurance & 33 & 36 & 35 & 33 & 30 & 29 \\
\hline \multicolumn{7}{|l|}{ Concentration } \\
\hline Commercial banks 2/ & 11 & 10 & 11 & 10 & 10 & 9 \\
\hline Securities companies 2/ & 3 & 3 & 3 & 4 & 2 & 2 \\
\hline Assets & \multicolumn{6}{|c|}{ (In billions of euros) } \\
\hline \multicolumn{7}{|l|}{ Banks } \\
\hline Commercial banks & $2,145.0$ & $2,402.8$ & $2,359.7$ & $2,440.4$ & $2,861.7$ & $3,610.4$ \\
\hline Private & $2,123.0$ & $2,323.9$ & $2,277.7$ & $2,365.3$ & $2,850.4$ & $3,598.8$ \\
\hline Domestic & $1,681.5$ & $1,884.6$ & $1,865.7$ & $1,982.5$ & $2,428.5$ & $3,004.1$ \\
\hline Foreign & 441.5 & 439.3 & 412.0 & 382.8 & 421.9 & 594.6 \\
\hline State-owned 1/ & 22.0 & 78.8 & 82.1 & 75.1 & 11.3 & 11.7 \\
\hline Credit unions and mutuals & 847.7 & 857.4 & 880.8 & 934.7 & $1,053.5$ & $1,127.0$ \\
\hline \multicolumn{7}{|l|}{ Other credit institutions } \\
\hline Finance companies & 411.2 & 473.9 & 507.9 & 536.2 & 432.7 & 405.2 \\
\hline Of which: mortgage institutions & 50.9 & 62.3 & 75.9 & 91.9 & 107.2 & 125.7 \\
\hline Specialized financial institutions & 46.4 & 46.8 & 42.9 & 46.9 & 40.4 & 21.2 \\
\hline Municipal credit institutions & 1.8 & 1.9 & 1.9 & 1.9 & 1.9 & 1.7 \\
\hline Securities firms & 44.1 & 51.9 & 64.9 & 218.7 & 215.3 & 270.6 \\
\hline \multicolumn{7}{|l|}{ Insurance companies (assets) } \\
\hline Life and retirement & 749.7 & 798.3 & 832.4 & 907.3 & 985.2 & $1,103.4$ \\
\hline Nonlife & 130.4 & 139.3 & 143.1 & 152.2 & 159.8 & 170.5 \\
\hline Reinsurance & 27.9 & 33.1 & 31.4 & 31.3 & 22.2 & 31.4 \\
\hline \multicolumn{7}{|l|}{ Deposits } \\
\hline \multicolumn{7}{|l|}{ Banks } \\
\hline Private commercial & 435.8 & 515.9 & 516.1 & 526.8 & 573.9 & 676.3 \\
\hline State-owned & 2.7 & 5.6 & 3.6 & 7.9 & 0.2 & 0.5 \\
\hline Foreign-owned subsidiaries & 44.2 & 50.8 & 52.7 & 47.7 & 45.2 & 56.6 \\
\hline Branches of foreign banks & 16.3 & 17.1 & 19.4 & 20.9 & 19.7 & 26.1 \\
\hline
\end{tabular}

Source: Banque de France; and Ministry of Finance.

$1 /$ Including development banks. Nonbank development finance corporations are included separately under "Other credit institutions."

2/ Number of institutions with 75 percent of total assets. 


\section{APPENDIX I: FRANCE: FUnd RELATIONS}

As of July 31, 2006

Mission: Paris, June 29-July 10, 2006. The concluding statement of the mission is available at http://www.imf.org/external/np/ms/2006/071006.htm.

Staff team: Messrs. Leipold (Head), Everaert, Luzio, Nadal De Simone, and Schule, and Mmes. Allard and Zoli (all EUR).

Country interlocutors: The minister of the economy, finance, and industry; the minister of the budget and the reform of the state; the governor of the central bank; the director general of the treasury; the directors of the budget, taxation, health, social affairs, and labor and their staffs; the economic advisor in the cabinet of the prime minister; the rapporteur of the finance commission of the National Assembly; INSEE; the Commission Bancaire; the Financial Market Authorities; the Council for Economic Analysis; representatives of labor unions, employer organizations, academia, and the financial sector. Mr. Duquesne (Executive Director) or Mr. Cuny (Alternate Executive Director) attended the meetings.

Fund relations: The previous Article IV Consultation took place on November 2, 2005. The associated Executive Board's assessment is available at http://www.imf.org/external/np/sec/pn/2005/pn05153.htm and the staff report at http://www.imf.org/external/pubs/ft/scr/2005/cr05399.pdf. France accepted the obligations under Article VIII and, apart from certain security restrictions, maintains an exchange system free of restrictions.

Data: France subscribes to the Fund's Special Data Dissemination Standard, and comprehensive economic data are available on a timely basis (Appendix II).

I. Membership Status: Joined December 27, 1945; Article VIII.

II. General Resources Account:

Quota

Fund holdings of currency

Reserve position in Fund
SDR Million

$10,738.50$

$9,315.08$

$1,423.58$

\section{Percent of Quota}

100.00

86.74

13.26 
III. SDR Department

Allocation
SDR Million Percent of

$1,079.87 \quad 100.00$

$623.16 \quad 57.71$

IV. Outstanding Purchases and Loans: None

V. Latest Financial Arrangements: None

VI. Projected Payments to Fund (SDR million; based on existing use of resources and present holdings of SDRs):

\begin{tabular}{lllll}
\multicolumn{6}{c}{ Forthcoming } \\
\hline$\underline{2006}$ & $\underline{2007}$ & $\underline{2008}$ & $\underline{2009}$ & $\underline{2010}$
\end{tabular}

Principal

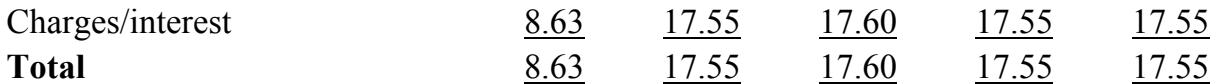

$\begin{array}{llllll}\text { Total } & \underline{8.63} & \underline{17.55} & \underline{17.60} & \underline{17.55} & \underline{17.55}\end{array}$

VII. Implementation of HIPC Initiative: Not applicable

VIII. Safeguards Assessments: Not applicable

IX. Exchange Rate Arrangements:

- Since January 1, 1999, France has participated in Stage III of the European Economic and Monetary Union (EMU).

- In accordance with EU regulations and the relevant UN Security Council resolutions, certain restrictions are maintained on the making of payments and transfers for current international transactions with respect to the former government of Iraq, the former government of Liberia, Myanmar, certain individuals associated with the previous government of the former Republic of Yugoslavia, and Zimbabwe. Financing of, and financial assistance related to, military activities in the Democratic Republic of the Congo (from October 1, 2003), Somalia (effective January 27, 2003), and Sudan (from January 26, 2004) are prohibited. Restrictions also apply on transfers with respect to the Taliban and individuals and organizations associated with terrorism. The restriction with respect to the Socialist People's Libyan Arab Jamahiriya has been notified to the Fund under Decision No. 144-(52/51). 
Measures have been taken to freeze accounts of listed persons and entities linked to terrorists pursuant to the relevant EU regulations and UN Security Council resolutions.

\section{Article IV Consultation:}

The last Article IV consultation was concluded on November 2, 2005. France is on the standard 12-month consultation cycle.

\section{FSAP Participation and ROSC:}

France-Report on the Observance of Standards and Codes (ROSC): Module I-Fiscal Transparency

Fiscal Transparency-Update

Fiscal Transparency-Update
October 17, 2000

IMF Country Report

No. 01/196, 11/05/01

IMF Country Report

No. 04/345, 11/03/04

Summary: The report found that France has achieved a high level of fiscal transparency and has introduced a number of improvements in coverage and presentation of fiscal information. Notable areas of progress include the development in the final accounts publication to include more complete information on government assets and liabilities as well as disclosure of contingent liabilities. Accounting standards have been changed to reflect accruals principles in a number of areas, and these standards are clearly explained. The staff suggested that further steps could be taken to identify and report quasi-fiscal activities in the budget presentation, provide a more consolidated picture of fiscal activity outside the appropriation process, and improve the reconciliation of stated policies with outcomes at the general government level.

These issues have been addressed in the Loi organique aux lois de finance (LOLF), which has become fully effective on January 1, 2006. In addition to the annual appropriations, the government has to commit to a multi-annual framework, details of which are provided in the economic, social, and financial report attached to the Budget Act. The budget is organized along missions and provides details on the level of appropriations for each mission and performance indicators by which the expected results of the mission will be assessed ex post. The State Audit Office has been given the new assignment of certifying the public accounts, and implementation of accruals-basis accounting has been confirmed. Parliamentary oversight powers have been strengthened. 
France-Report on the Observance of Standards and Codes (ROSC): Module II-Transparency in Monetary and Financial Policies

\section{Transparency in Monetary and Financial Policies-Update}

Transparency in Monetary and Financial Policies-Update
October 2000, corrected: $2 / 15 / 01$

IMF Country Report No. $01 / 197,11 / 05 / 01$ IMF Country Report No. $02 / 248,11 / 13 / 02$

Summary: The 2000 ROSC noticed that transparency of financial policies is accorded a high priority by all financial agencies assessed, and they are in observance of the good practices of the Code of Good Practices on Transparency in Monetary and Financial Policies. The major agencies disclose their objectives, their legal and institutional frameworks, and have open processes of policymaking and regulation. The principles of transparency are observed by dissemination of relevant information to the public and in the agencies' arrangements for internal conduct, integrity, and accountability. However, the staff noted that the framework for supervision and regulation applicable to mutual insurance firms is not as well defined and suggested to improve its transparency. The transparency of monetary policy was not assessed by the Fund team as the Banque de France is a member of the European System of Central Banks and no longer conducts independent monetary policy.

Subsequently, the framework for supervision and regulation applicable to a specific group of mutual insurance firms was modified in a number of steps. In August 2003, legislation created a single supervisory body, the Commission de Contrôle des Assurances, Mutuelles et Institutions de Prévoyance (CCAMIP) by merging the regular insurance supervisor (CCA) and mutualities' supervisor (CCMIP). Coordination with the banking sector supervisors was strengthened and the powers of the supervisory authorities extended.

France-Report on the Observance of Standards and Codes (ROSC): Data Module

Data Module-Update

Data Module-Update
IMF Country Report

No. 03/339, 10/2903

IMF Country Report

No. $04 / 345,11 / 03 / 04$

IMF Country Report

No. $05 / 398,11 / 07 / 05$

Summary: The report found that France is in observance of the Fund's Special Data Dissemination Standard (SDDS). In particular, the mandate of INSEE and the Banque de France for the production of the six macroeconomic datasets is clearly defined, with the reporting burden and the confidentiality provisions given special consideration notably 
through the CNIS. Professionalism is central to the statistical operations of the two institutions, internationally and/or European accepted methodologies are generally followed, the degree of accuracy and reliability of the six datasets is remarkable, statistics are relevant and provided on a timely basis, and they are accessible to the public.

The report made a number of suggestions for further improvements: the responsibility of INSEE as the producer of government finance statistics should be clarified; data sharing between the Banque de France and the rest of the French statistical system improved; classification and valuation methods in balance-of-payments statistics reviewed; consistency between the current account of the balance of payments and the goods and services account in the national accounts improved; the timing of revisions in the quarterly and annual national accounts aligned; and identification of data production units of INSEE facilitated.

France continues to implement several of the 2003 ROSC Data Module recommendations, including by promoting a broader understanding of statistical data revisions, making greater use of firm-level data to improve the measurement of changes in stocks, and intensifying work on portfolio investment income with the objective of starting to record those transactions on an accrual basis.

France-Financial System Stability Assessment (FSSA)

FSAP Assessment and Reports on ROSCs

FSAP Assessment
IMF Country Report

No. $04 / 344,11 / 03 / 04$

IMF Country Report

No. 04/345, 11/03/04

IMF Country Report

No. 05/185, 06/08/05

\section{IMF Country Report \\ No. 05/186, 06/08/05 \\ Publication of FSAP_Detailed Assessment of Observance of Standards and Codes}

Summary: The report concluded that France's financial sector is strong and well supervised. No weaknesses that could cause systemic risks were identified. The strength of the system is supported by the financial soundness indicators and the strong conformity to the supervisory and regulatory standards approved by the Basel Committee, IAIS, IOSCO, FATF, and CPSS. The degree of observance of the transparency code is high in all relevant areas. The French banking sector has been modernized and restructured over the past two decades and is well capitalized. Systemic vulnerabilities in the important insurance sector are well contained. Securities markets are large and sophisticated.

Notwithstanding the strengths of the French financial sector, a number of issues emerged from the FSAP, including (i) concentration in banking may have reached a point where further consolidation could intensify concerns over the scope for collusion and long-term 
stability where many banks could be considered "too big to fail;" (ii) banks' large and growing portfolios of fixed-rate residential housing loans could represent a longer-term risk in the event of large increases in funding costs and/or a significant fall in real estate prices; (iii) some administered savings schemes and other policy measures give rise to costs and impede financial market innovation. These schemes are not well targeted to achieve intended social goals and are not well aligned with current priorities, such as strengthening the pension system; (iv) the banking system's rapid accumulation of capital strengthens banks' resilience. This accumulation is harder to control for mutual banks, given their legal restrictions on remuneration of their members. And, for all banks, it could encourage expansion through expensive takeovers and risky new ventures; (v) the supervisory system of the financial sector is composed of specialized segments. Coordination mechanisms need to be further adapted. Additional steps should be considered in the future as cross-sectoral financial groups become more prevalent; (vi) the consolidation of the French stock and futures markets with others in Europe has increased the importance of effective cooperation across national jurisdictions. Moreover, the authorities face the challenge of adjusting to and effectively implementing the significant regulatory overhaul that took place in late 2003; and (vii) the infrastructure for the clearing and settlement of payments and securities is generally sound and modern. However, there is some room for improvement in the clearing and settlement of retail payments and securities, where the multilateral netting systems lack fully adequate safeguards to ensure timely settlement in case of default. 


\section{APPENDIX II: FRANCE: STATISTICAL ISSUES}

France's economic database is comprehensive and of high quality, and data provision to the Fund is adequate for surveillance. The authorities regularly publish a full range of economic and financial data, and calendar dates of main statistical releases are also provided. The transmission of data in electronic form from INSEE (Institut national de la statistique et des études économiques) and the profusion of data from various institutions (Banque de France, INSEE, ministry of finance, ministry of labor and solidarity) have helped to build an infrastructure, in which all data can be easily accessed through the Economic Data Sharing System. As a subscriber to the Special Data Dissemination Standard (SDDS), France posts its metadata on the Fund's Dissemination Standards Bulletin Board (DSBB) on the Internet. A data ROSC mission conducted an assessment of the statistical system in March 2003, and the report was published in October 2003. A factual update to the main report was published in November 2004.

Since the beginning of 1999, France's monetary and banking statistics methodology has changed to reflect the standards of the European Economic and Monetary Union. The European Central Bank framework, which is used by the authorities for reporting monetary data to STA, provides comparable details as the Standardized Report Forms developed by STA. Statistics for International Financial Statistics on banking institutions and monetary aggregates are prepared on a monthly basis and are timely. France's monetary data have been included in the September 1, 2006 issue of the quarterly IFS Supplement No 17 on monetary and financial statistics.

France adopted the European System of Integrated Economic Accounts 1995 (ESA95) in 1999. Data for GDP and its expenditure components are available from 1978 onwards. Both annual and quarterly accounts provide reliable information, although estimates from the two accounts differ slightly before the quarterly accounts are revised to be aligned to the annual ones. In 2005, national accounts data were rebased to 2000 prices. While current and constant 2000 prices are available, institutional sector data are only available from 1993 onwards and employment data from 1990 onwards. INSEE will publish in the near future the complete set of national accounts with base 2000, and starting in 1978.

Data issues include the need to provide monthly or quarterly developments not only for the finances of the central government, but also for social security and local governments. These data should be presented in a comprehensive fashion and on a national accounts basis to facilitate monitoring of public finances. The national accounts website has recently been

enhanced: it includes expenditure tables and government revenues by subsector (central 
government, miscellaneous central government agencies, local governments, and social security administration).

With regard to balance-of-payments statistics, the data ROSC mission recommended initiating efforts to achieve greater coherence between the external current account and the rest of the world account in national accounts. Work with promising early results has been undertaken on the transportation account. 


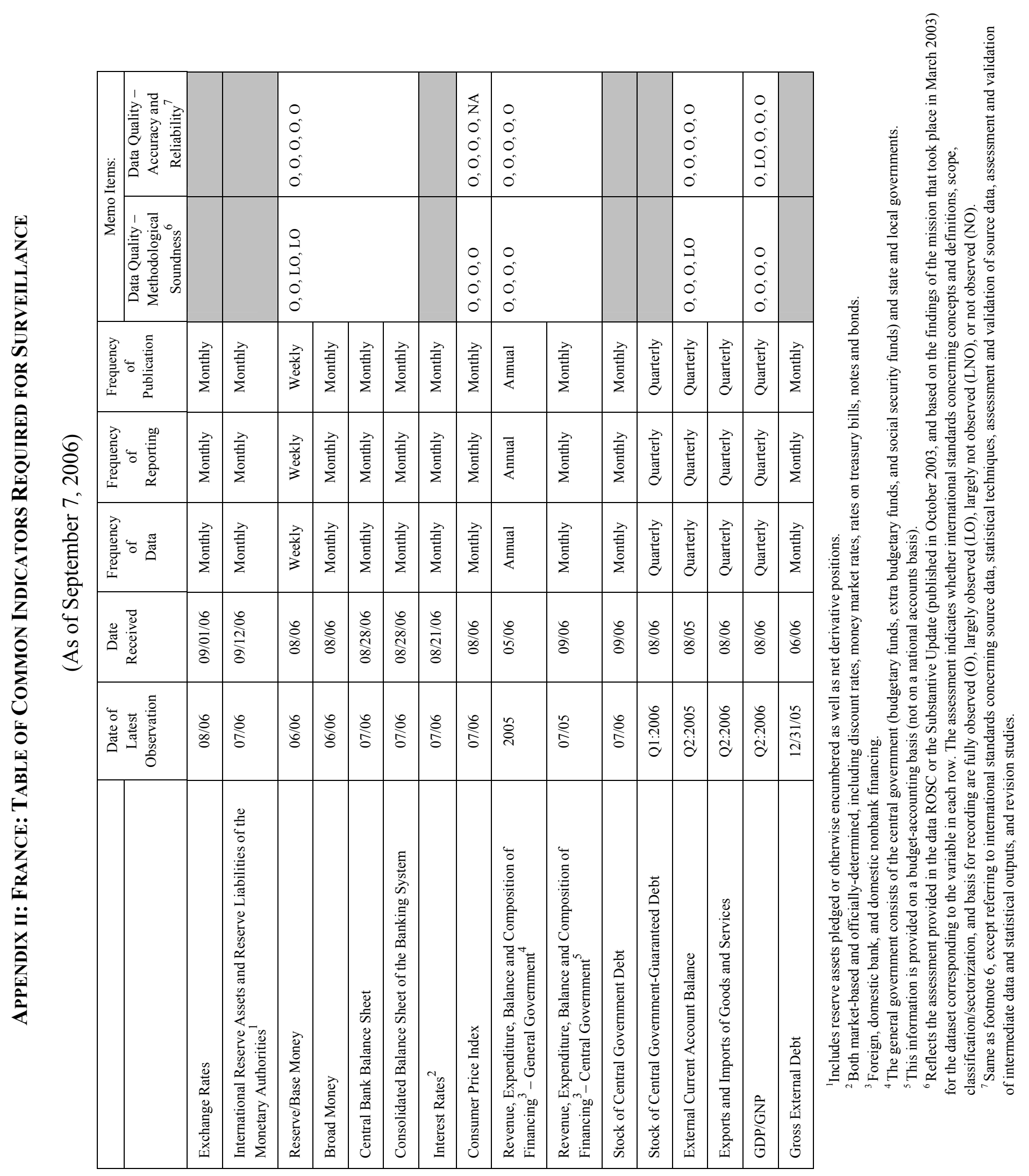




\title{
INTERNATIONAL MONETARY FUND
}

\section{FRANCE}

\section{Staff Report for the 2006 Article IV Consultation Supplementary Information}

\author{
Prepared by the European Department \\ (In consultation with the Policy Development and Review Department) \\ Approved by Michael Deppler and Matthew Fisher
}

October 19, 2006

This supplement to the staff report for the 2006 Article IV Consultation with France provides an update on recent developments, in particular the authorities' 2007 budget proposal and their medium-term fiscal plans presented with the budget. The new information does not alter the thrust of the staff appraisal.

\section{Summary}

Growth is likely to reach 2.5 percent in 2006, slightly higher than anticipated in the staff report because of historical data revisions, but growth rates going forward remain unchanged, consistent with newly released short-term economic indicators. Headline inflation fell to 1.5 percent in September, helped by declining oil prices. The staff's growth projections are somewhat higher than those of the authorities, leading it to project general government deficits of 2.6 percent of GDP and 2.4 percent of GDP in 2006 and 2007, respectively, compared to official targets of 2.7 percent and 2.5 percent of GDP. Tight spending control and slightly above-trend nontax revenues are expected to accommodate previously announced tax cuts of about 0.3 percent of GDP. In the staff's estimates, the structural deficit is set to remain broadly constant in 2007, while the authorities see a continuing structural improvement. The 2007 budget raises spending on ODA to 0.5 percent of GNI. On structural issues, privatization is continuing, but the removal of administered schemes in the financial sector is being resisted.

\section{Output and inflation}

1. The authorities project growth in a range of 2-2 $2 \frac{1}{2}$ percent in 2006 and 2007, on the basis of robust consumer spending. The staff projections are at the top end of this range in 2006 and at 2.3 percent for 2007, above the Consensus forecast (Table 1). Recent data 
releases are consistent with growth settling at about $2 \frac{1}{2}$ percent in the second half of 2006 . Consumer confidence is up, and spending on manufactured goods was exceptionally strong in August. Industrial production weakened during the summer, but business sentiment held up well, and the outlook for production has been improving. Labor shortages have emerged in a briskly expanding construction sector. Higher oil prices and buoyant imports led to a further widening of the current account deficit in July, despite strong export growth. Employment has been edging up, but the unemployment rate rose marginally to 9 percent in August, following a 1 percentage point decline over the past 12 months. Headline inflation has moderated while the slight upward trend in underlying inflation was reversed in AugustSeptember 2006, with a decline to 1.0 percent.

\section{Budget}

2. Owing to stronger growth, the reduction in the 2006 general government deficit is larger than expected, and underlying adjustment is still expected to amount to 0.5 percent of GDP. The authorities project the deficit to fall from 2.9 percent of GDP in 2005 to 2.7 percent of GDP in 2006, below the initial target of 2.9 percent of GDP. The structural adjustment results from the replacement of one-off revenues (transfer of the energy utilities' pension funds) with durable expenditure restraint. In social security, tight control of health care spending appears to be more than offsetting higher-than-budgeted pension payments. Fiscal incentives favoring energy conservation have been strengthened, with marginal budgetary implications. As noted in the staff report, tax expenditure approved outside the budget law appears to be weighing on the budget and is estimated to have reduced revenues by 0.1 percent of GDP in 2006 .

\section{Budget}

3. The draft 2007 budget aims to reduce the deficit from 2.7 percent to 2.5 percent of GDP while lowering the tax burden. With growth assumed to be $2 \frac{1}{4}$ percent, this is to be accomplished as follows:

- On the expenditure side, general government spending is set to grow by 1.4 percent in real terms, for a 0.4 percent decline in the expenditure-to-GDP ratio. Central government expenditure is planned to fall by 1 percent in volume terms after three consecutive years of zero real growth. The number of civil servants will decline by 15,000 (in full-time equivalents), a step-up from the record to date, but still implying a replacement rate of four out of five retiring employees. Nominal social security spending growth is projected to stabilize at about $3 \frac{11}{4}$ percent, anchored by a health care spending norm of 2.5 percent. To achieve this, new measures will be introduced to foster the use of generic drugs and reduce fraud. However, pension payments will rise as an increasing number of baby boomers are retiring. Local government expenditures are expected to continue growing above nominal GDP, reflecting strong investment and a rising wage bill. 
- $\quad$ Revenues from taxes and social security contributions are projected to fall by 0.3 percentage point to 43.7 percent of GDP. Two thirds of this decline stem from a preannounced income tax reform, which reduces the number of brackets and the highest marginal rates. In addition, the earned income tax credit (prime pour l'emploi) is being raised further, and firms will benefit from the capping of the taxe professionnelle at 3.5 percent of value added, the exemption of new investment from this tax, and the elimination of social security contributions for minimum wage workers in small firms. The budget again stipulates that all revenue windfalls be applied to deficit reduction. Nontax revenues are maintained at slightly above-trend levels.

4. In the authorities' estimates, the 2007 budget implies a structural adjustment of 0.4 percent of GDP. However, this adjustment reflects the assumption that potential growth is significantly higher than actual projected growth of 21/4 percent of GDP in 2007 and particular assumptions about the behavior of structural revenues. On the basis of the staff's already upward-revised estimates of potential growth (see staff report $\$ 14$ ) and unit elasticity of revenues with respect to GDP, there would be virtually no underlying adjustment in 2007.

\section{Medium-term fiscal outlook}

5. Over the medium term (2008-10), the authorities intend to pursue underlying adjustment through expenditure restraint, while leaving the tax system unchanged. In their "low-case" medium-term scenario, growth is set to continue at $2 \frac{1}{4}$ percent per year, and real general government spending growth would decline further to average 0.6 percent during 2008-10 (Text Table). Central government spending would decelerate to become constant in value by 2010 , and social security, health care, and local spending growth would be limited, respectively, to 1.1 percent, 2.2 percent, and 2 percent per year in real terms. This scenario would result in a cumulative structural adjustment of 2.2 percentage points of GDP by 2010 . As measures to achieve these objectives have not been specified, the staff projects that on current policies, real general government spending would average 1.8 percent per year beyond 2007, limiting the improvement of the structural balance to 0.3 percent of GDP by 2010 . The authorities also present a high-case medium-term scenario with higher actual and potential annual economic growth of 3 percent due to structural reforms. Excluding tax cuts and taking into account lower spending on unemployment benefits, this scenario would improve the fiscal situation by almost 1 percent of GDP.

\section{Structural issues}

6. Parliament approved an energy law paving the way for divestiture of Gaz de France (GDF), while the authorities sharply criticized EU attempts to challenge the distribution monopoly of an administered savings scheme (Livret $A$ ). 
Text Table. France: 2007 Budget and Medium-Term Fiscal Plans

(In percent of GDP)

\begin{tabular}{lrrrrrr}
\hline & & \multicolumn{5}{c}{ Projection } \\
\cline { 5 - 7 } & 2005 & 2006 & 2007 & 2008 & 2009 & 2010 \\
\hline Budget 2007 1/ & & & & & & \\
$\quad$ Overall balance & -2.9 & -2.7 & -2.5 & -1.8 & -0.9 & 0.0 \\
Tax revenue & 44.0 & 44.0 & 43.7 & 43.5 & 43.5 & 43.5 \\
Expenditures & 53.8 & 53.3 & 52.9 & 52.1 & 51.3 & 50.4 \\
Real expenditure growth (in percent) & 2.3 & 1.4 & 1.4 & 0.9 & 0.7 & 0.4 \\
Real GDP growth (in percent) & 1.2 & 2.3 & 2.3 & 2.3 & 2.3 & 2.3 \\
CPI inflation excluding tobacco (in percent) & 1.8 & 1.8 & 1.8 & 1.8 & 1.8 & 1.8 \\
Staff projections (current policies) & & & & & & \\
Overall balance & -2.9 & -2.6 & -2.4 & -2.2 & -2.0 & -1.7 \\
Tax revenue & 44.0 & 44.0 & 43.7 & 43.5 & 43.5 & 43.5 \\
Expenditures & 53.8 & 53.2 & 52.8 & 52.4 & 52.0 & 51.7 \\
Real expenditure growth (in percent) & 2.3 & 1.4 & 1.4 & 1.6 & 1.7 & 1.8 \\
Real GDP growth (in percent) & 1.2 & 2.5 & 2.3 & 2.4 & 2.4 & 2.4 \\
CPI inflation excluding tobacco (in percent) & 1.8 & 1.8 & 1.8 & 1.8 & 1.7 & 1.7 \\
Structural balance 2/ & -2.2 & -1.7 & -1.7 & -1.7 & -1.6 & -1.4 \\
\hline
\end{tabular}

Sources: Authorities; and IMF staff calculations.

1/ The medium-term plans correspond to the "lower scenario" in the authorities' draft budget.

2/ Excluding the EDF pension transfer in 2005.

\section{Staff Assessment}

7. While the 2007 budget envisages continued spending restraint, it is partly used to fund tax cuts, with an inopportune pause in underlying adjustment. Economic projections underlying the 2007 budget are cautious, and the planned reduction in central government expenditure by 1 percent in real terms represents a welcome breakthrough, building on the successful real containment of recent years. However, on the basis of the staff's more conservative estimates of potential growth and structural revenue behavior, there is virtually no structural adjustment in 2007. The tax reform improves incentives and economic efficiency. To be effective, the budget provision to allocate revenue windfalls to deficit reduction will need to be complemented by a rule prohibiting tax expenditure from being implemented outside the budget law.

\section{For the medium term, the considerable reduction in spending as a share of GDP} envisaged by the authorities will require the adoption of durable expenditure measures. On current policies, the staff projects the structural balance to remain in a deficit of about $1 \frac{1}{2}$ percent of GDP over the medium term. Implementing the authorities' planned spending path for the central government, balancing social security budgets and curbing local spending growth would eliminate this deficit. Even so, as illustrated in the staff report, fiscal sustainability will only be achieved with further growth-enhancing structural reforms. 
Table 1. France: Main Economic Indicators, 2002-11

(Annual percentage change; unless otherwise indicated)

\begin{tabular}{|c|c|c|c|c|c|c|c|c|c|c|}
\hline & \multirow[b]{2}{*}{2002} & \multirow[b]{2}{*}{2003} & \multirow[b]{2}{*}{2004} & \multirow[b]{2}{*}{2005} & \multicolumn{6}{|c|}{ Projection } \\
\hline & & & & & 2006 & 2007 & 2008 & 2009 & 2010 & 2011 \\
\hline \multicolumn{11}{|l|}{ Demand and supply in constant prices $1 /$} \\
\hline Gross domestic product & 1.1 & 1.1 & 2.0 & 1.2 & 2.5 & 2.3 & 2.4 & 2.4 & 2.4 & 2.4 \\
\hline Private consumption & 2.4 & 2.2 & 2.5 & 2.1 & 2.7 & 2.5 & 2.5 & 2.4 & 2.4 & 2.4 \\
\hline Public consumption & 1.9 & 2.0 & 2.2 & 1.1 & 2.5 & 2.2 & 2.1 & 2.2 & 2.1 & 2.1 \\
\hline Gross fixed investment & -1.7 & 2.2 & 2.6 & 3.7 & 3.9 & 3.0 & 2.8 & 2.9 & 2.8 & 2.8 \\
\hline Business investment & -3.1 & 1.3 & 2.4 & 3.5 & 4.5 & 3.8 & 3.7 & 3.7 & 3.6 & 3.6 \\
\hline Public investment & -1.0 & 6.0 & 2.2 & 3.9 & 3.6 & 2.8 & 2.2 & 2.2 & 2.1 & 2.1 \\
\hline Stockbuilding 2/ & -0.3 & -0.3 & 0.3 & 0.0 & -0.2 & -0.1 & 0.0 & 0.0 & 0.0 & 0.0 \\
\hline Total domestic demand & 1.2 & 1.9 & 2.8 & 2.1 & 2.7 & 2.5 & 2.4 & 2.5 & 2.4 & 2.4 \\
\hline Foreign balance $2 /$ & -0.1 & -0.7 & -0.7 & -1.0 & -0.3 & -0.2 & -0.1 & -0.1 & 0.0 & 0.0 \\
\hline Exports of goods and NFS & 1.3 & -1.1 & 3.3 & 3.2 & 8.4 & 6.8 & 6.6 & 6.5 & 6.5 & 6.5 \\
\hline Imports of goods and NFS & 1.6 & 1.5 & 6.0 & 6.4 & 8.9 & 6.9 & 6.5 & 6.4 & 6.3 & 6.3 \\
\hline \multicolumn{11}{|l|}{ Prices } \\
\hline GDP deflator & 2.4 & 1.8 & 1.7 & 1.8 & 1.9 & 1.7 & 1.7 & 1.7 & 1.7 & 1.7 \\
\hline Consumer prices (end of period) 4/ & 2.2 & 2.4 & 2.3 & 1.8 & 1.5 & $\cdots$ & $\cdots$ & $\cdots$ & $\cdots$ & $\cdots$ \\
\hline \multicolumn{11}{|l|}{ Employment and wages } \\
\hline Employment & 0.6 & 0.1 & 0.0 & 0.5 & 0.7 & 0.6 & 0.5 & 0.5 & 0.5 & 0.5 \\
\hline Unemployment 5/ & 8.9 & 9.5 & 9.6 & 9.5 & 8.9 & 8.4 & 8.1 & 7.7 & 7.4 & 7.0 \\
\hline Productivity $6 /$ & 0.5 & 1.0 & 2.0 & 0.7 & 1.8 & 1.7 & 1.9 & 1.9 & 1.9 & 1.9 \\
\hline Unit labor costs (whole economy) & 3.0 & 1.8 & 1.3 & 1.8 & 1.6 & 1.8 & 1.7 & 1.5 & 1.5 & 1.5 \\
\hline Output in manufacturing & -0.4 & 0.9 & 1.2 & 1.6 & 4.5 & 5.0 & 4.0 & 3.0 & 2.0 & 2.0 \\
\hline Hourly labor compensation in manufacturing & 3.3 & 3.3 & 3.5 & 3.1 & 3.9 & 4.5 & 3.0 & 2.7 & 2.0 & 2.0 \\
\hline Unit labor costs in manufacturing & 0.2 & -0.7 & -1.1 & -1.7 & -0.6 & -0.5 & -1.0 & -0.3 & 0.0 & 0.0 \\
\hline \multicolumn{11}{|l|}{ Personal sector } \\
\hline Real disposable income $7 /$ & 3.7 & 1.1 & 2.5 & 1.3 & 2.6 & 2.6 & 2.5 & 2.4 & 2.4 & 2.4 \\
\hline Savings ratio $8 /$ & 16.9 & 15.8 & 15.8 & 14.9 & 14.9 & 15.0 & 15.0 & 14.9 & 14.9 & 15.0 \\
\hline Output gap 9/ & 0.0 & -0.9 & -0.9 & -1.7 & -1.3 & -1.1 & -0.9 & -0.6 & -0.4 & 0.0 \\
\hline Rate of growth of potential output & 2.1 & 2.0 & 2.1 & 2.1 & 2.1 & 2.2 & 2.2 & 2.2 & 2.2 & 2.1 \\
\hline \multicolumn{11}{|l|}{ Balance of payments } \\
\hline Trade balance (in billions of euros) & 8.0 & 2.9 & -6.9 & -25.9 & -29.2 & -29.8 & -30.5 & -30.7 & -30.6 & -30.2 \\
\hline (in percent of GDP) & 1.0 & 0.4 & -0.3 & -1.6 & -1.9 & -1.9 & -1.9 & -1.8 & -1.7 & -1.6 \\
\hline Terms of trade & 2.6 & -0.1 & -0.3 & -1.5 & -0.6 & 0.2 & 0.2 & 0.2 & 0.2 & 0.2 \\
\hline Nominal effective exchange rate $10 /$ & 101.7 & 106.1 & 107.6 & 107.7 & 108.5 & $\ldots$ & $\ldots$ & $\ldots$ & $\ldots$ & $\ldots$ \\
\hline Real effective exchange rate $10 /$ & 97.8 & 101.0 & 102.2 & 101.3 & 101.7 & $\ldots$ & $\ldots$ & $\ldots$ & $\ldots$ & $\ldots$ \\
\hline \multicolumn{11}{|l|}{ Public sector accounts 11/ } \\
\hline Revenue & 49.5 & 49.2 & 49.6 & 50.9 & 50.6 & 50.4 & 50.2 & 50.0 & 50.0 & 50.0 \\
\hline Expenditure & 52.7 & 53.4 & 53.2 & 53.8 & 53.2 & 52.8 & 52.4 & 52.0 & 51.7 & 51.4 \\
\hline General government balance 12 / & -3.2 & -4.2 & -3.7 & -2.9 & -2.6 & -2.4 & -2.2 & -2.0 & -1.7 & -1.4 \\
\hline Central Government balance 12/ & -3.7 & -3.9 & -3.2 & -3.0 & -2.5 & -2.1 & -1.7 & -1.4 & -0.9 & -0.4 \\
\hline Social Security balance 12/ & -0.2 & -0.6 & -1.0 & -0.2 & -0.4 & -0.6 & -0.8 & -0.8 & -0.9 & -0.9 \\
\hline Structural balance 12/ 13/ & -3.1 & -3.5 & -3.0 & -2.2 & -1.7 & -1.7 & -1.7 & -1.6 & -1.4 & -1.4 \\
\hline Primary balance & -0.3 & -1.4 & -1.0 & -0.2 & 0.0 & 0.2 & 0.3 & 0.5 & 0.8 & 1.1 \\
\hline Gross debt $12 /$ & 58.2 & 62.4 & 64.4 & 66.6 & 64.4 & 63.3 & 62.7 & 61.9 & 61.1 & 60.0 \\
\hline
\end{tabular}

Sources: Banque de France; data provided by the authorities; and IMF staff estimates.

1 / Data from the INSEE quarterly national accounts system.

2/ Change as percentage of previous year's GDP.

3/ Harmonized CPI.

4/ For 2006, year-on-year September

5 / In percent of labor force; harmonized index.

6/ GDP over total employment.

7/ Personal disposable income deflated by the implicit deflator for private consumption.

8/ In percent of household disposable income.

9/ In percent of potential GDP.

10/ Index; Base 2000=100. For 2006, data available up to August.

11/ In percent of GDP; data for 2001-02 exclude the proceeds from the sale of UMTS licenses, which amount to about 0.1 percent of GDP.

12/ Maastricht definition.

13/ Data for 2005 exclude the EDF pension fund transfer ( 0.5 percent of GDP); in percent of potential GDP. 


\section{INTERNATIONAL MONETARY FUND}

Public Information Notice (PIN) No. 06/127

FOR IMMEDIATE RELEASE

November 1, 2006
International Monetary Fund

$70019^{\text {th }}$ Street, NW

Washington, D. C. 20431 USA

\section{IMF Executive Board Concludes 2006 Article IV Consultation with France}

On October 25, 2006, the Executive Board of the International Monetary Fund (IMF) concluded the Article IV Consultation with France. ${ }^{1}$

\section{Background}

After stagnating in the first half of 2005 , economic activity rebounded strongly, supported by robust domestic demand. The uptick in neighboring countries' GDP growth buttressed exports, following three years of weakness despite buoyant global demand. From a longer-term perspective, France's relative performance has, however, lagged the ongoing global expansion, as indicated by the decline in its ranking in terms of per capita GDP from $12^{\text {th }}$ to $16^{\text {th }}$ position during the past five years.

All components of domestic demand contributed to the upswing. Falling unemployment, real increases in minimum wages, and low interest rates supported consumption and investment in housing. Fixed capital formation strengthened with the revived cyclical upturn. The external sector detracted from growth over the past five years, and together with adverse terms-of-trade effects, led to a shift in the current account into deficit. Structural factors, including labor market rigidities, limit the economy's ability to rapidly adjust to developments in trade partners and take advantage of robust global growth.

The staff projects GDP growth to remain broad-based, averaging 2.5 percent in 2006 and 2.3 percent in 2007, reflecting the slowdown in global growth. Headline inflation is trending down in line with falling energy prices, and staff projects it to decline to

\footnotetext{
${ }^{1}$ Under Article IV of the IMF's Articles of Agreement, the IMF holds bilateral discussions with members, usually every year. A staff team visits the country, collects economic and financial information, and discusses with officials the country's economic developments and policies. On return to headquarters, the staff prepares a report, which forms the basis for discussion by the Executive Board. At the conclusion of the discussion, the Managing Director, as Chairman of the Board, summarizes the views of Executive Directors, and this summary is transmitted to the country's authorities.
} 
1.8 percent in 2007 from an average of 2 percent in 2006. In line with improved demographic trends and reflecting the impact of ongoing structural reforms, the staff has raised its potential growth outlook to 2.2 percent for the next five years, after which it will be dampened as a result of population aging.

The 2007 draft budget targets a reduction in the general government deficit to 2.5 percent of GDP from 2.7 percent of GDP in 2006 and 2.9 percent of GDP in 2005. Following a structural improvement of about 0.8 percentage point of GDP in 2005, the staff estimates the structural balance to improve by 0.5 percentage point of GDP in 2006. Structural adjustment is achieved through expenditure restraint at the central government level and in health care. The net tax burden remains roughly constant in 2006, but is expected to decline by 0.3 percent of GDP in 2007 , largely due to tax relief favoring work income, investment, and a variety of smaller tax cuts in other areas.

In the financial sector, housing credit expanded strongly, bank profitability increased, and nonperforming loans declined. Supervisors urged banks to strengthen loan standards and watch exposure to hedge funds and credit derivatives. New mortgage market instruments have been established.

On structural reforms, the authorities are emphasizing the need to raise public awareness of the benefits of structural reforms. Labor supply is being promoted by the increase in earned income tax credit and the reduction in marginal income tax rates, while labor demand is benefiting from targeted reductions in social security contributions and the introduction of a new labor contract for small enterprises (Contrat nouvelle embauche, CNE). A reorganization of employment services is designed to improve labor market matching. Following the withdrawal of a proposed new labor contract for the young (Contrat première embauche, CPE) in light of social protests, a council on employment (Conseil d'orientation pour l'emploi, COE) was created to establish a common diagnosis of the causes of unemployment and foster public debate on its remedies. In product markets, divestiture from commercial activities has continued, including in the energy sector.

\section{Executive Board Assessment}

Directors commended the French authorities for their skillful macroeconomic management in recent years and welcomed the significant progress in fiscal consolidation and structural reform. Noting that France has changed more than is commonly perceived, Directors supported the authorities' emphasis on building consensus, which has been instrumental in promoting reform. However, much remains to be done. Directors encouraged the authorities to continue with a steadfast pursuit of their consensus-building approach to advance the key reforms needed to increase potential growth, durably reduce unemployment, prepare for an aging population, and allow the economy to benefit fully from globalization. Equally, Directors urged the authorities to maintain the steady pace of fiscal consolidation until the general government budget is balanced. 
Directors saw the near-term economic outlook as positive, with growth becoming more vigorous and broad based, while improved demographics and structural reforms have brightened the medium-term outlook. Falling unemployment, rising wages, and tax cuts have supported private consumption, and inflation has remained low, while favorable financing conditions and high capacity utilization are bolstering investment. Although exports have strengthened noticeably since mid-2005 following a few years of lackluster performance, the current account deficit has continued to widen. The real effective exchange rate appears to be fairly valued, and Directors did not see an immediate competitiveness problem. However, they noted the lack, until recently, of a more dynamic response of exports to the global expansion. This underscores the importance of flexibility-enhancing structural reforms, which will also be helpful in addressing the risk of a disorderly unwinding of global imbalances.

Directors supported the authorities' emphasis on informing, educating, and consensusbuilding to foster public support for economic reforms. They observed that this approach has worked well in the area of public finances, with broad consensus on the need to curb deficits and debt, and that this consensus now needs to be extended to labor and product market reforms. Directors encouraged the authorities to exploit synergies and balance various interests by advocating reforms covering several areas, and giving consideration to their proper sequencing. Directors saw three issues as standing at the top of the agenda: further fiscal adjustment through expenditure restraint; further labor market reform by reducing the judicial uncertainty surrounding permanent contracts and widening the differentials between out-of-work benefits, the minimum wage, and the median wage; and further product market reform through deregulation of the services sector and progressive disengagement of the state from commercial activities.

Directors urged the authorities to continue to make significant progress with fiscal consolidation by maintaining the pace of adjustment of recent years. They welcomed the prospect that the 2006 deficit outcome appears set to come in below the budget target, bolstering the credibility of fiscal policy. For 2007, Directors welcomed the intention to reduce central government expenditures by 1 percent in real terms and to sustain the decline in health-spending growth, but observed that pension and local government spending remains buoyant. Directors were of the view that stronger adjustment in 2007 would be desirable to maintain an evenly-paced path toward balance.

Directors supported the authorities' objective of balancing the budget by 2010 , as a crucial component of the strategy to deal with population aging. As the recent fiscal consolidation has mainly relied on increases in revenues, Directors strongly welcomed the focus on ambitious medium-term expenditure restraint, while emphasizing the need to make the specific policy choices required to achieve this objective. In particular, Directors stressed the importance of reducing spending growth for social security and local governments. 
Directors welcomed the contribution of recent tax reforms to improving incentives and economic efficiency, thanks to their focus on making work pay and on fostering investment. Directors saw merit in further reductions in the tax burden, which should be funded by an additional decline in spending and a broadening of the tax base.

Directors welcomed the full implementation of the new objective-oriented budgeting framework for the central government that has helped strengthen fiscal governance. In this context, they felt that the provision to allocate revenue windfalls to deficit reduction adopted in the last two budgets should become a standard feature. To avoid circumvention of this provision and safeguard the benefits of tight spending control, Directors underscored the need to formally prevent recourse to tax expenditure outside the framework of the budget law. Directors welcomed the reliance on consensusbuilding institutions to promote fiscal discipline and contribute to the public debate on fiscal policy, and looked forward to further development of this approach.

Directors observed that the financial system is highly profitable, well capitalized, and in a good position to manage increasing risks. They nevertheless urged supervisors to remain highly attentive to the risks of relaxation of loan standards and rising exposures abroad and to less liquid market segments. Directors saw scope for increasing the financial sector's contribution to economic growth. To achieve this objective, administered saving schemes should be phased out, competition and the development of risk capital markets promoted, and the complete integration of Europe's financial markets advanced.

Directors noted that the labor market has become more flexible following recent reforms, while observing that increases in the minimum wage continue to curb labor demand and intensify wage compression. In this context, Directors underscored the need to break the vicious circle between minimum wage increases and the use of budgetary resources to reduce labor costs. Instead, they felt that the focus should be squarely placed on reforms to raise labor market flexibility. Hence, Directors urged the authorities to increase the wedge between the minimum wage and the median wage and between out-of-work benefits and the minimum wage to reward the return to work and career progression. An important step to boost job creation will be to reduce the legal uncertainty surrounding permanent labor contracts.

Directors welcomed the steps toward divestiture of network industries and the reduction in the administrative burden on enterprises. They noted that these reforms would boost output and consumer welfare and that their further pursuit would lend support to labor market reforms. Directors encouraged the authorities to make determined efforts on economic deregulation, divestiture from commercial activities, and further opening up of the services markets to competition. 
Directors urged France to contribute actively within the EU to help revive and bring to a successful conclusion the Doha round of multilateral trade negotiations.

They welcomed France's commitment to supporting developing countries and the planned increase in its official development assistance.

Public Information Notices (PINs) form part of the IMF's efforts to promote transparency of the IMF's views and analysis of economic developments and policies. With the consent of the country (or countries) concerned, PINs are issued after Executive Board discussions of Article IV consultations with member countries, of its surveillance of developments at the regional level, of post-program monitoring, and of ex post assessments of member countries with longer-term program engagements. PINs are also issued after Executive Board discussions of general policy matters, unless otherwise decided by the Executive Board in a particular case. 
France: Selected Economic Indicators

(Annual percentage change; unless otherwise indicated)

$2002 \quad 2003 \quad 2004 \quad 2005 \quad 20061 /$

\begin{tabular}{|c|c|c|c|c|c|}
\hline \multicolumn{6}{|l|}{ Real economy (change in percent) } \\
\hline Real GDP & 1.1 & 1.1 & 2.0 & 1.2 & 2.5 \\
\hline Domestic demand & 1.2 & 1.9 & 2.8 & 2.1 & 2.7 \\
\hline CPI (year average) & 1.9 & 2.2 & 2.3 & 1.9 & 2.0 \\
\hline Unemployment rate (in percent) & 8.9 & 9.5 & 9.6 & 9.5 & 8.9 \\
\hline Gross national savings (percent of GDP) & 20.0 & 19.3 & 19.1 & 18.6 & 18.4 \\
\hline Gross domestic investment (percent of GDP) & 19.0 & 18.9 & 19.4 & 20.2 & 20.3 \\
\hline \multicolumn{6}{|l|}{ Public finance (percent of GDP) 2/ } \\
\hline Central government balance & -3.7 & -3.9 & -3.2 & -3.0 & -2.5 \\
\hline General government balance & -3.2 & -4.2 & -3.7 & -2.9 & -2.6 \\
\hline General government gross debt & 58.2 & 62.3 & 64.5 & 66.7 & 64.3 \\
\hline \multicolumn{6}{|l|}{ Money and interest rates } \\
\hline Money market rate (in percent) 3/ & 3.3 & 2.3 & 2.1 & 2.2 & 3.4 \\
\hline Government bond yield (in percent) 4/ & 4.9 & 4.2 & 4.2 & 3.5 & 3.8 \\
\hline \multicolumn{6}{|l|}{ Balance of payments (percent of GDP) } \\
\hline Trade balance & 0.5 & 0.2 & -0.4 & -1.5 & -1.6 \\
\hline Current account & 1.0 & 0.4 & -0.3 & -1.6 & -1.9 \\
\hline Official reserves (US\$ billion) 5/ & 28.4 & 30.2 & 32.5 & 27.8 & $\ldots$ \\
\hline \multicolumn{6}{|l|}{ Fund position (as of August 31,2006 ) } \\
\hline Holdings of currency (percent of quota) & & & & & 87.0 \\
\hline Holdings of SDRs (percent of allocation) & & & & & 58.0 \\
\hline Quota (SDRs million) & & & & & $10,738.5$ \\
\hline \multicolumn{6}{|l|}{ Exchange rates } \\
\hline Exchange rate regime & \multicolumn{5}{|c|}{ Participant in EMU } \\
\hline Euro per U.S. dollar (September 28, 2006) & & & & & 1.27 \\
\hline Nominal effective rate $(2000=100) 6 /$ & 100.4 & 101.7 & 106.2 & 107.6 & 107.5 \\
\hline Real effective exchange rate $(2000=100) 6 / 7 /$ & 98.7 & 99.8 & 103.5 & 104.4 & 102.8 \\
\hline
\end{tabular}

Sources: Data provided by the authorities; and IMF staff estimates.

$1 /$ Staff projections.

2/ Data for 2001-02 exclude the proceeds from the sale of UMTS licenses, which amount to about 0.1 percent of GDP.

3/ Data refer to the interbank rate (as from 1999 onwards). For 2006, data are as of January-September.

4/ Average yield to maturity on public sector bonds with original maturities of more than five years. The figure for 2006 refers to August.

5/ Excluding gold, end-of-period; eurosystem definition. The figure for 2006 refers to August.

6/ The figure for 2006 refers to August.

7/ Based on relative normalized unit labor costs in manufacturing. 